\title{
Degradation of Haloaromatic Compounds
}

\author{
K. H. Engesser and P. Fischer
}

\section{Economical and Ecological Relevance of Halogenated Aromatic Hydrocarbons (HAHs)}

An ever increasing number of halogenated organic compounds has been produced by industry in the last few decades. These compounds are employed as biocides, for synthetic polymers, as solvents, and as synthetic intermediates. Production figures are often incomplete, and total production has frequently to be extrapolated from estimates for individual countries.

Hexachlorobenzene production, for instance, was estimated at about 10000 tonne $\mathrm{yr}^{-1}$ in the 1970s (Rippen and Frank 1986). Total polychlorobenzene production, since its introduction to industrial use, has been calculated at roughly 750000 tonne (Reineke and Knackmuss 1988). About two thirds of this overall production are accredited to have entered closed processes. Consequently, 250000 tonne must have been released more or less directly into the environment. Around 1980, world production of pentachlorophenol was reported as 40000 tonne $\mathrm{yr}^{-1}$ most of which can be supposed to have entered into the environment. 1,4-Dichlorobenzene production, at

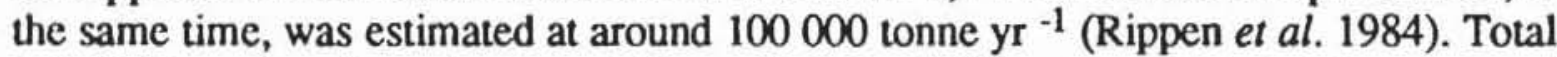
2,4-dichlorophenol production at the end of the 1970s was calculated in excess of 70000 tonne $\mathrm{yr}^{-1}$ (Behret 1989).

Compounds of this type as a rule are highly persistent against biodegradation and belong, as "recalcitrant" chemicals, to the class of so-called xenobiotics. This term is used to characterise chemical substances which have no or limited structural analogy to natural compounds for which degradation pathways have evolved over billions of years. Xenobiotics frequently have some common features, e.g. high octanol/water partitioning coefficients and low water solubility which makes for a high accumulation ratio in the biosphere (bioaccumulation potential) (Johnson and Kennedy 1973). 
Recalcitrant compounds therefore are found accumulated in mammals, especially in fat tissue, animal milk supplies (Frank and Braun 1989), and also in human milk (Collins et al. 1982; Ip and Phillips 1989; Skaare and Polder 1990). Highly sophisticated analytical techniques have been developed for the detection of organochlorines at the trace and ultratrace level (Burse et al. 1990).

Chlorinated aromatic compounds in many cases display acute or chronic toxicity for humans, with the probability also of mutagenic, cancerogenic (Nesnow et al. 1986), and teratogenic effects (Magnus-Francis 1990). Moreover, HAHs frequently are contaminated with highly pemicious polychlorinated dibenzofurans and dibenzodioxins (Hagenmaier 1986). Because of extreme biological effects at very low concentration (Whitlock 1990, Ryan et al. 1990, Safe 1990), many HAHs have been included in the list of "Priority Pollutants". This list expresses the public concern about uncontrolled use of these chemicals (Keith and Telliard 1979), and at the same time recognises the tremendous waste disposal problems (Levine and Chitwood 1985).

For a possible microbial clcan-up of environmental contamination, one has to differentiate clearly between "point source" and "dispersed" pollution. In the first case, large amounts of chemicals, in high concentration, are present in one location (landfills, waste dumps, industrial effluents, accidental spills). In dispersed pollution, chemical concentration is low but spread over a large area or volume. Different strategies of bioremediation are required for these two types of pollution.

There are also diverse natural sources for HAHs. Marine aquifers, for example, produce a number of brominated compounds (Siuda and DeBemardis 1973, Neidleman and Geigert 1987, Wannstedt et al. 1990). The presence of such chloro and bromo compounds, especially in marine environments, has presented a challenge to microorganisms which sometimes develop astonishing degradative capabilities for these halogenated structures.

Biodegradation of HAHs is covered in a number of reviews (Reincke and Knackmuss 1988; Reineke 1986; Ribbons et al. 1987; Häggblom 1990; Ghosal et al. 1985; Commandeur and Parsons 1990; Rochkind-Dubinsky et al. 1986; Leisinger and Brunner 1986; Neilson 1990; Rasul-Chaudry and Chapalamadugu 1991) which concentrate inter alia on single classes of HAHs, on ecological aspects, on genetics or on bioremediation techniques. In the present review, special emphasis is placed on the mechanisms by which halide is liberated from organic molecules (Table 2.1).

In sharp contrast to aliphatic halides (Knackmuss 1981), the carbon-halogen bond in aryl halides is not susceptible to hydrolysis by nucleophilic displacement reactions. Frequently, halide elimination is observed only as a secondary process after metabolic transformation of the HAHs to non-aromatic, i.e. aliphatic or olefinic intermediates ("late" elimination). In the course of an alternative mechanism, enzyme-mediated addition of hydroxyl groups or other nucleophiles or of electrophiles (e.g. hydratation, epoxidation, dioxygenation) is followed by elimination of $\mathrm{H}-\mathrm{Hal}$ ("early" elimination). Reductive halide displacement represents a third mechanistic possibility.

The term "(bio)degradation" will be used in this review only when HAHs are completely mineralised, with stoichiometric release of halide, i.e. synonymous with biomineralisation. In contrast, processes will be characterised as "(bio)transformation" which result in some structural alteration only of the substrate. Frequently, only the disappearance of the substrate is monitored without establishing either the carbon balance or the stoichiometry of the overall reaction. This is likewise subsumed under the term "(bio)transformation" which thus may also cover incomplete metabolisation.

There is reason to assume that such biotransformation processes (also called "cometabolism") represent a major way for the removal of recalcitrant compounds from 
Table 2.1. Representative examples for bacterial degradation or transformation of haloarenes

\begin{tabular}{|c|c|c|c|}
\hline Class of compounds & Bactenal strain/genus & $\begin{array}{l}\text { Mech- } \\
\text { anism }\end{array}$ & Reference \\
\hline \multicolumn{4}{|l|}{ 1. Halobenzoales } \\
\hline 4-chlorobenzoate & Pseudomonas & $\mathrm{H}$ & Klages and Lingens 1980 \\
\hline 3-chlorobenzoate & Pseudomonas sp. B13 & E & Dom el al. 1974 \\
\hline polyhalobenzoates & Pseudomonas aeruginosa JB2 & $?$ & Hickey and Focht 1990 \\
\hline 2-chlorobenzoate & Pseudomonas & E & Hartmann et al. 1989 \\
\hline $\begin{array}{l}3-, 4-\text {, and } 3,5- \\
\text { dichlorobenzoate }\end{array}$ & Pseudomonas & $\mathrm{E}$ & Hartmann et al. 1979 \\
\hline 2-halobenzoates & Pseudornonas putida CLB250 & 0 & Engesser and Schulte 1989 \\
\hline 4-chlorophenylacetate & Pseudomonas & 0 & Klages et al. 1981 \\
\hline 2,4-dichlorobenzoatc & Alcalıgenes denitnficans & $\mathrm{R} / \mathrm{H}$ & van den Tweel et al. 1987 \\
\hline 4-chlorobenzoate & Nocardia & $\mathrm{H}$ & Klages and Lingens 1979 \\
\hline \multicolumn{4}{|c|}{2 Halophenoxyalkanoales (Halo-PAs) } \\
\hline 4-chloro-2-methyl-PA & Pseudomonas & $\mathrm{E}$ & Gaunt and Evans 1971a,b \\
\hline 2,4-dichloro- / 4-chloro-2- & Alcalıgenes eutrophus & $\mathrm{E}$ & Pieper et al. 1988 \\
\hline
\end{tabular}

\section{Halophenols \\ monochlorophenols polychlonnated phenols dichlorophenols monochlorophenols}

polychlorinated phenols polychlorinated phenols

\section{Halobenzenes}

dichloro- and

trichlorobenzenes

1,2-dichlorobenzene

1,4-dichlorobenzene

\section{Haloanilines}

monochlorinated anilınes monochlorinated anılines
Pseudomonas

Pseudomonas putida

Rhodococcus sp. ANi11.

AN213

Flavobacterium

Mycobacterium

Pseudomonas

Pseudomonas

Alcaligenes

Pseudomonas acidovorans Pseudomonas?
E Knackmuss and Hellwig 1978

H,R,O Apajalahti + Salkinoja-S.'87

E Spain and Gibson 1988

E Janke et al. 1989

O?, R Saber and Crawford 1985

HI?, Häggblom et al 1988

O?, B

E.OP? van der Meer et al. 1991

E Haigler et al. 1988

E Schraa et al. 1986

E Loidl et al. 1990

E Latorre et al. 1984

6. Polychlorobiphenyls (PCB)

PCBs

PCBs

PCBs

PCBs

\section{Halobiarylethers}

4-fluoro-4'-carboxybi-

phenylether

chlonnated dibenzofurans

\section{Miscellaneous}

Diethylsımazine

DDT

5-chloro-2-

hydroxynicotinic acid

Alcaligenes/Acinetobacter

Alcaligenes eutrophus

Acinetobacter

Enrichment cultures

(B*) Furukawa et al. 1978

(B*) Bedard et al. 1987

? Adriaens and Focht 1990

R(B) Quensen et al. 1988

Pseudomonas

Engesser et al. 1990

Alcaligenes

?
Rhodococcus corallinus Aerobacter acrogenes Mycobacterium
H Cook and Hütter 1986

E/R Wedemeyer 1967

E/H? Tibbles et al. $1989 b$

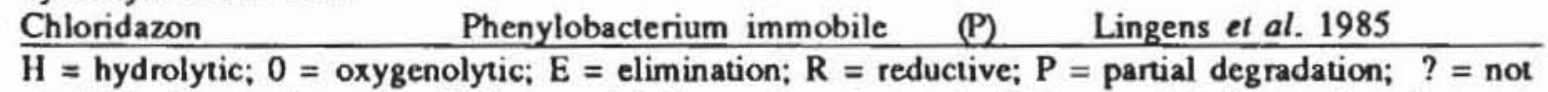
established unequivocally; $\left(\mathrm{B}^{*}\right)=$ no dehalogenation observed; $\left(\mathrm{P}^{*}\right)=$ no dehalogenation observed 


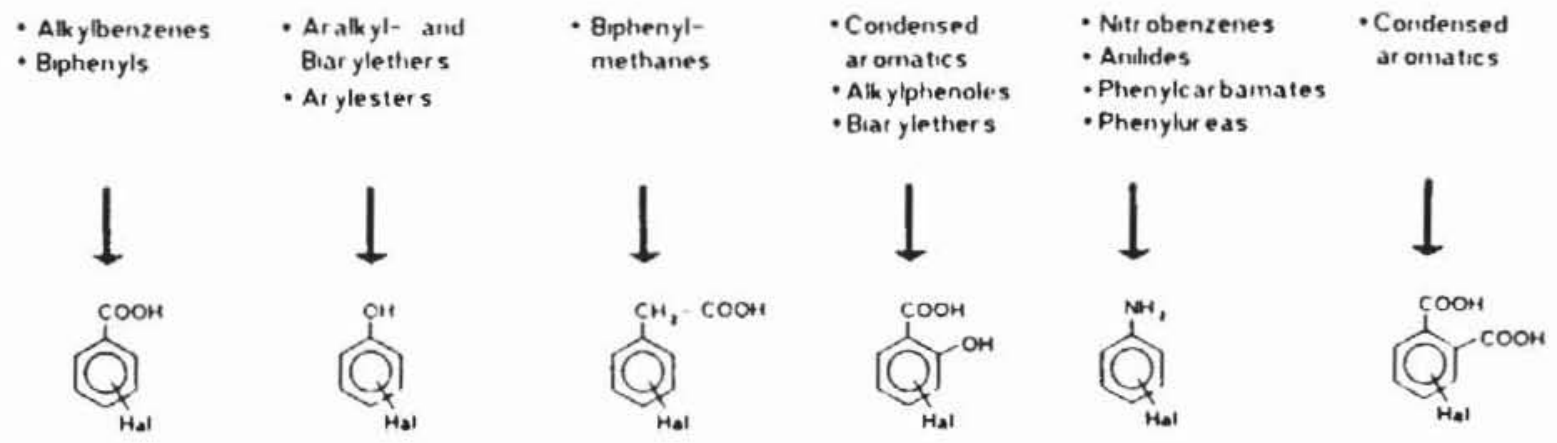

Fig. 2. 1. Central intermediates of haloarene degradation.

the biosphere (Knackmuss 1981). A series of non- or pre-adapted enzymes may transform a substrate stepwise, without energy being derived from the individual reactions. This works only if the co-substrates deliver sufficient energy to maintain the induction and metabolic potential of the active microorganisms. Alternatively, a substrate may be degraded only partially, with the microorganism deriving growthsustaining energy from these processes, which may be termed "partial degradation".

\section{Channelling of Complex Haloarene Structures into Key Intermediates: the Importance of Model Compounds for Degradation Studies}

Among the different haloarenes, produced by industry, there are sometimes extremely toxic compounds such as TCDD (2,3,7,8-tetrachlorodibenzo- $\rho$-dioxin), PCP (pentachlorophenol), PCBs (polychlorinated biphenyls), and HCB (hexachlorobenzene). Some HAHs are at the same time highly polar and of high molecular weight (chlorinated and sulfonated lignin components), or very insoluble and toxic (halogenated dibenzofurans and dibenzodioxins). In the "early days" of haloarene degradation research, investigations were therefore confined to readily water-soluble mono- and dihalosubstituted benzoates and phenoxyalkanoates. These substrates are easily degradable, and biochemical studies were consequently speeded up.

Figure 2.1 demonstrates that the degradation of many haloarenes, with great structural variety, may be channelled into a limited number of central intermediates (Dagley 1978). A bouquet of so-called "peripheral" enzymes transforms all kinds of haloarenes into a few mononuclear haloaromatic structures, such as benzoic acids, salicylates, anilines, and phenols. Chloro-substituted phenoxyalkanoates, chloronaphthalines, and chlorobiphenyls, for instance, are transformed by these peripheral sequences. Biodegradation of 4,4'-dichlorobiphenyl affords 4-chlorobenzoate as an essential intermediate (Kimbara et al. 1988), closely following the degradation pathway for biphenyl (see Fig. 2.1). Chlorinated benzoic acids are also reported as intermediates of polychlorinated biphenyl (PCB) degradation, independent of chlorine content. 


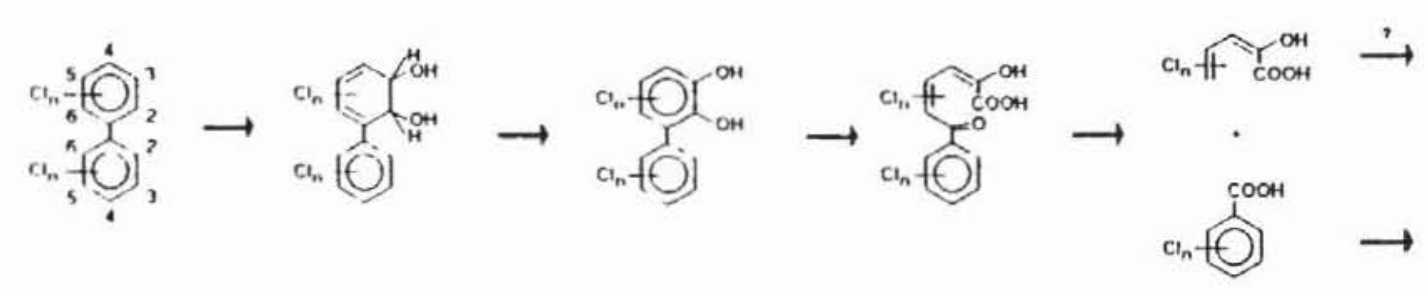

Fig. 2.2. Aerobic degradation of polychlorinated biphenyls by an Achromobacter species.

\section{Polychlorinated Biphenyls (PCBs)}

Following an early report on the aerobic degradation of polychlorinated biphenyls by an Achromobacter species (Ahmed and Focht 1973), an overwhelming amount of information has been presented by many different groups (Ballschmiter et al. 1977; Baxter et al. 1975; Furukawa and Matsumura 1976; Furukawa et al.; 1978, Furukawa et al. 1979). The biochemistry of PCB transformation was generally described as analogous to the established pathway of biphenyl catabolism (see Fig. 2.2) (Omori et al. 1986; Catelani et al. 1971). In a first step, halo-substituted phenylcatechols are formed intermediately by action of biphenyl 2,3-dioxygenases and 2,3-dihydro-2,3dihydroxybiphenyl dehydrogenases. Subsequent meta-cleavage and hydrolysis of the ring cleavage product gives chloro-substituted benzoates from one phenyl ring and 2-oxo-4-pentenoates, with a varying number of chlorines, from $t^{\text {th }}$ other (Shields et al. 1985; Kimbara et al. 1988; Kilpi et al. 1988; Adriaens et al. 1989). In some cases, (chlorophenyl)glyoxylic acids or chlorinated acetophenones are accumulated, indicating the existence of other marginal biotransformation pathways (Shiaris and Sayler 1982; Bedard et al. 1987). From Kanechlor $400^{\mathrm{R}}$ (a technical PCB mixture of mainly tetrachlorobiphenyls), chlorobenzoates, dihydroxy compounds (supposedly chlorocatechols), and meta-cleavage compounds, all with two to four chlorine substituents, are produced during metabolisation by an Acinetobacter species (Furukawa et al. 1983). More heavily chlorinated PCBs are metabolised only slightly, with dihydroxypentachlorobiphenyl derivatives being detected as sole metabolites.

Aerobic biotransformation of PCBs via biphenyl-related pathways seems to be subject to some structural restrictions which are mostly due to the prevalent 2,3-dioxygenation mode of cometabolic attack on PCBs:

1 An increasing number of chlorine substituents generally decreases biodegradation rates in aerobic systems; consequently, $\mathrm{PCB}$ congeners with more than five chlorines are virtually not transformed (Bedard et al. 1987).

2 One unsubstituted ring facilitates biotransformation.

3 One ring at least must have one ortho and the adjacent meta position unsubstituted.

Steric screening by the bulky chlorine atoms renders such PCB congeners, where all ortho and/or meta positions are blocked, not or only slightly biodegradable. As mentioned above, PCBs generally are attacked via 2,3-dioxygenation (Safe 1984). Some microorganisms seem to possess a different set of biphenyl degrading enzymes by which PCB congeners are attacked, unexpectedly, in 3,4-position (Bedard et al. 1986). Bacteria of this type (e.g. Corynebacterium sp MB1 and Alcaligenes eutrophus H850) are able to oxygenate, in addition to lower chlorinated PCBs, even $2,5,2^{\prime}, 5^{\prime}$ tetrachloro-, 2,4,5,2',5'-pentachloro- and, albeit slower, 2,4,5,2',4',5'hexachlorobiphenyl, with unusual metabolites such as chlorinated acetophenones being formed. 
All microorganisms, described so far as competent for PCB transformation, do not use PCBs with more than two chlorine substituents as sole source of carbon (Bedard $e t$ al. 1986; Adriaens et al. 1989; Shields et al. 1985). The respective transformations thus must be termed cometabolic. For one mixed culture, growing solely on a PCB cocktail containing mostly tetrachlorobiphenyls, it has not been clarified whether the microorganism in fact used the higher chlorinated congeners for growth (Kimbara et al. 1988).

If biphenyl is added to facilitate any energy-consuming biotransformation process, PCBs under such relaxed conditions are more susceptible to microbial attack (Focht and Brunner 1985; Brunner et al. 1985). For example, after addition of both an Acinetobacter strain P6 and biphenyl to PCB-containing soil, up to $27 \%$ of labeled $\mathrm{PCB}$ was recovered as ${ }^{14} \mathrm{CO}_{2}$. Addition of the microorganism alone, without biphenyl, did not improve biodegradation (Brunner el al. 1985). Likewise, degradation of 4-chlorobiphenyl, as a PCB model, was greatly enhanced by addition of the 4-chlorobiphenyl-degrading bacterium Alcaligenes A4 (Hill et al. 1989). The strain survives sufficiently long in soil to offer the opportunity for its application in bioremediation processes.

In most of the experiments reviewed above, only PCB substrate disappearance was monitored. Due to the very low biotransformation rates (Bedard et al. 1987) and the difficulty of measuring chloride in soil matrices, no stoichiometry of chloride release is given as a rule. There are indications, however, of cometabolic chloride release, after meta-cleavage of chloro-substituted phenyl catechols, being a feasible though highly inefficient process (Adriacns and Focht 1990).

The halobenzoates, haloacetophenones or other metabolic intermediates, generated by these cometabolic PCB-degrading processes, should in principle be converted to halocatechols. It cannot be ruled out, however, that other pathways are involved.

\section{Chlorinated N-Heterocycles}

Enzymes of biphenyl-degrading organisms have been found to be rather unspecific. Accordingly, heterocyclic biphenyl analogues likc Antipyrin and Chloridazon are partially degraded by e.g. Phenylobacterium immobile and similar strains since the bacteria can utilise at least one phenyl ring as a source of carbon and energy (Lingens et al. 1985). The hete-rocyclic moiety is not degraded at all, and is accumulated quantitatively. Comparative analysis of some $16 \mathrm{~S}$-ribosomal nucleic acid partial sequences showed that this microorganism constituted a new genus even though the transformation pathway for the heterocyclic substrates is identical, except for one enzyme, with that of the biphenyl-degrading organisms (Ludwig et al. 1984). Intensive

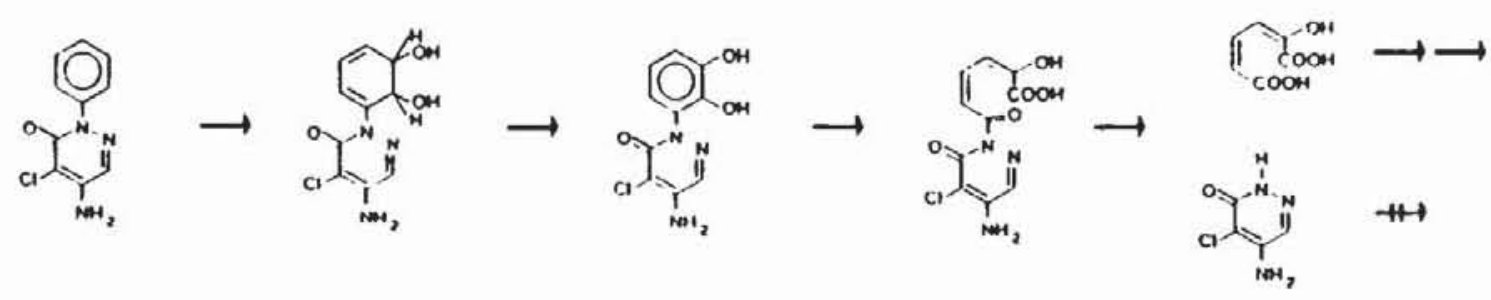

Fig. 2.3. Chlorinated $N$-heterocycle degradation by Phenylobacterium immobile. 


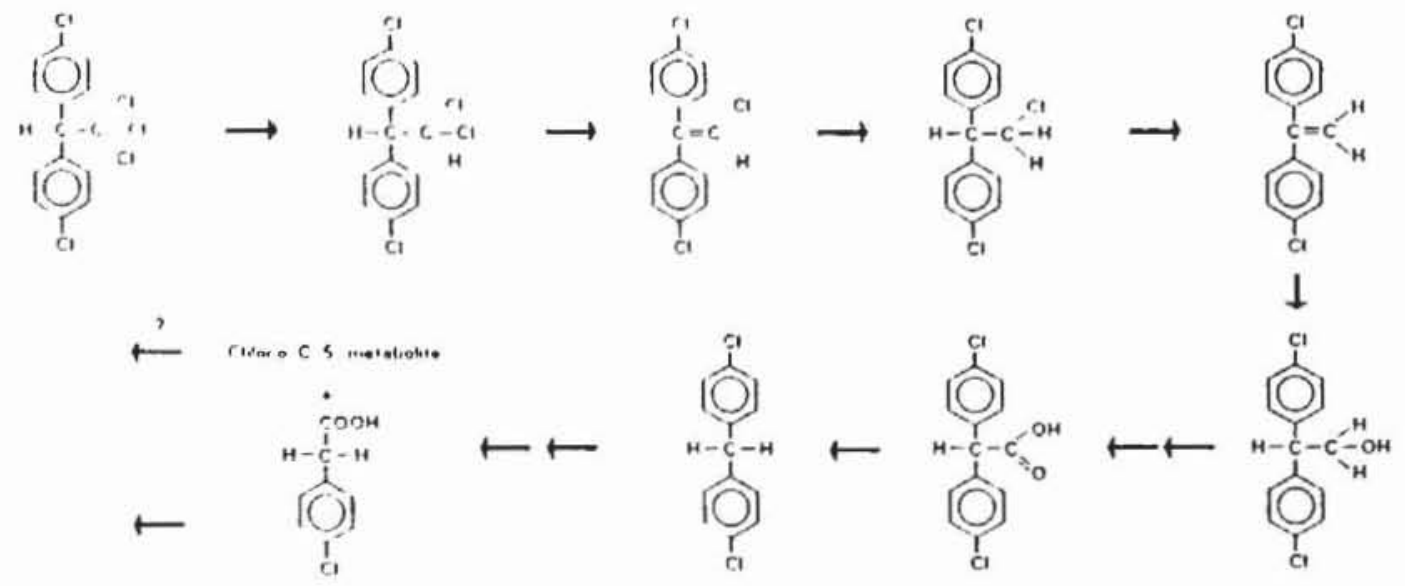

Fig. 2.4. Co-metabolısm of DDT by a Klebsiella (Aerobacter) aerogenes strain.

characterisation of the $\mathrm{N}$-heterocycle pathway enzymes (see Fig. 2.3) revealed this to be an amidase which releases the C-6 metabolite, 4-oxalocrotonate (2-hydroxymuconate), instead of the C-5 metabolite 2-0xo-4-pentenoate, generated by regular hydrolase activity (Schmitt et al. 1984; Sauber et al. 1977). These Chloridazon-degrading bacteria also possess a hydrolase-type enzyme, the presence of which could be demonstrated after growth on cinnamic acid (Tittmann et al. 1980).

A similar process has bcen described for the transformation and partial utilisation of 3-chloroquinoline-8-carboxylic acid by Pseudomonas spec. EK III. The heterocycle is degraded to the dead-end product 5-chloro-2-hydroxynicotinic acid and pyruvate which serves as the principal carbon source (Tibbles et al. 1989a). Another bacterium can utilise this nicotinic acid derivative for growth (see Hydrolytic Displacement of Halogen).

\section{1,1,1-Trichloro-2,2-bis(4-chlorophenyl)ethane (DDT)}

DDT was transformed cometabolically (see Fig. 2.4) by a Klebsiella aerogenes (Aerobacter aerogenes) strain, via reductive dechlorination, to 1,1-dichloro-2,2-bis (4-chlorophenyl)ethene (DDD). In a second step, $\mathrm{HCl}$ is eliminated from the DDD and the double bond hydrogenated. The 1-chloro-2,2-bis(4-chlorophenyl)ethane thus formed finally yiclds 4,4'-dichlorobenzophenone and 4,4'-dichlorodiphenylmethane (Wedemeyer 1967). Other authors have shown these metabolites to be cometabolised, by a diphenylmethane-degrading Hydrogenomonas strain, to 4-chlorophenylacetate (Focht and Alexander 1970, Focht and Alexander 1971) which already has been demonstrated to be smoothly degradable (see Oxygenolytic Elimination of Halogen).

In a combined anacrobic/acrobic process, this Hydrogenomonas strain was found to first dechlorinate the DDT side chain and, in a second stage, metabolise the $4,4^{\prime}$ dichlorodiphenylmethane to a (4-chlorophenyl)acetate and chlorinated ring cleavage products (see Fig. 2.4). DDT was later also reported to be degraded very slowly in a similar experiment with a Pseudomonas aeruginosa strain. With lactate as co-substrate, the trichloromethyl moicty was claimed to be transformed to a carboxyl group under anacrobic or microaerophilic conditions (Golovleva and Skryabin 1981), followed by decarboxylation and reductive dechlorination of both rings. The resulting 


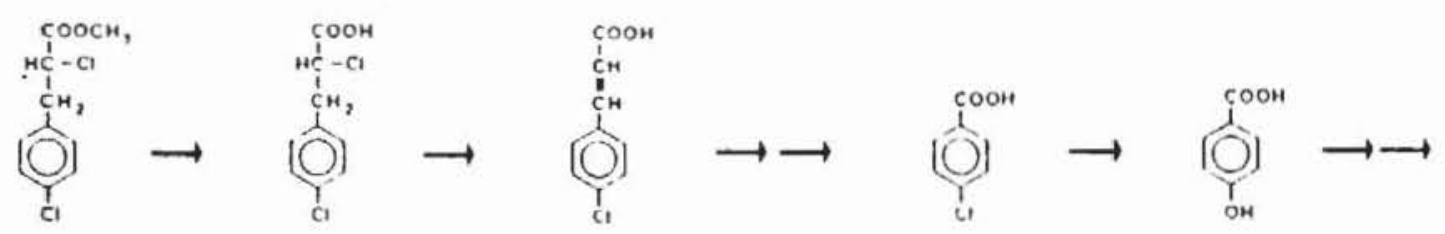

Fig. 2.5. Degradation of the herbicide Bidisin.

biphenylmethane was proposed as source of carbon and energy under aerobic conditions (Golovleva and Skryabin 1981). In some cases, reductive removal of chlorine precedes metabolism by acrobic microorganisms. This will be dealt with separately (see Liberation of Halide by Reductive Mechanisms).

\section{Bidisin}

Degradation of the herbicide Bidisin, methyl 2-chloro-3-(4-chlorophenyl)propionate), demonstrates strikingly how a complex structure is channeled into the established catabolic pathway for a basic structure (in this case 4-chlorobenzoate). After hydrolysis of the ester function, the aliphatic chlorine is eliminated, yielding 4-chlorocinnamate (see Fig.2.5). 4-Chlorobenzoate is formed in the ensuing steps according to the regular fatty acid oxidation pathway. This intermediate undergoes hydrolytic dechlorination to 4-hydroxybenzoate (see Hydrolytic Displacement of Halogen) which in turn is smoothly degraded (Köcher el al. 1976).

\section{Chloronaphthalines}

Knowledge concerning degradation of chloronaphthalines is scarce. Chlorosalicylates have been shown to be intermediates in the transformation of 1- and 2 chloronaphthaline (Morris and Barnsley 1982) and 1,4-dichloronaphthaline (Durham and Stewart 1987). Metabolic sequences dissimilating naphthalene via salicylate obviously are responsible for these reactions which, however, do not sustain growth of the organisms (see also Dehalogenation of Halocatechols after Meta-Cleavage).

\section{Halogenated Biarylethers}

As indicated above, little is known about degradation pathways for halogenated biarylethers (Rast et al. DBP 1990). Tumover even of the heavily chlorinated 2,3,7,8tetrachlorodibenzo-p-dioxin was reported although no products of these (gencrally very slow) processes were characterised (see for example Quensen and Matsumtra 1983). This is partially due to the sometimes highly dangerous properties of halogenated biaryl ethers, and to their very limited solubility. Quite recently, degradation of a model compound, 4-carboxy-4'-fluorodiphenyl ether, was described (Engesser et al. 1990a), 4-fluorophenol being found to accumulate quantitatively in the growth medium (see Fig. 2.6). 


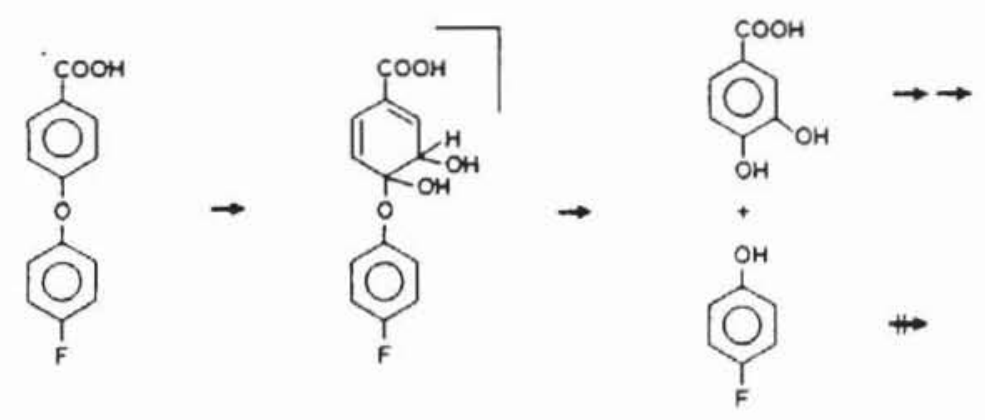

Fig. 2.6. Degradation of a model halogenated biarylether, 4-carboxy-4'-fluorodiphenyl ether.<smiles>Oc1ccc(Br)cc1</smiles><smiles>C[In]</smiles><smiles>Ic1ccccc1</smiles><smiles>C=CC</smiles><smiles>Oc1ccccc1O</smiles>
$\mathrm{A}=\mathrm{COOH}$ $\mathrm{R} \cdot \mathrm{H}$

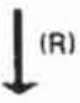<smiles>[Te]c1ccccc1</smiles>

Fig. 2.7. Three routes for the degradation of mononuclear benzene derivatives.
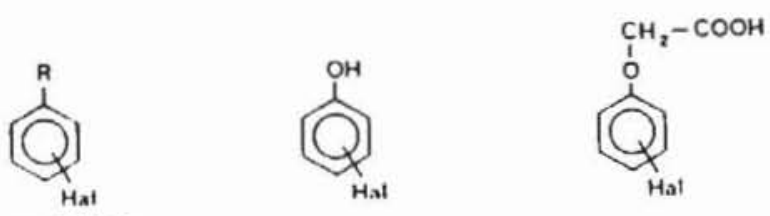<smiles>O=C(O)c1ccccc1O</smiles><smiles>Nc1ccccc1</smiles>

R. $\mathrm{COOH}$
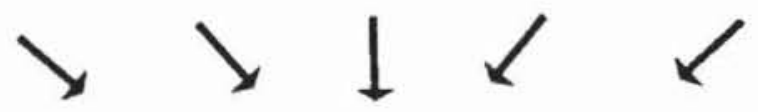<smiles>Oc1ccccc1O</smiles>

Fig. 2.8. Precursors for the halocatechol branch of mononuclear benzene degradation.

\section{Chlorocatechols as Central Intermediates in Metabolisation of Chlorinated Aromatic Structures}

As shown above, many complex haloaromatic structures are reduced to the limited number of basic mononuclear structures collated in Figure 2.1. Further metabolisation of these benzene derivatives proceeds along three different routes (see Fig. 2.7): 
1 "hydrolytic" or monooxygenolytic displacement of halide yielding monohydroxy benzene structures (Horvath 1971);

2 reductive liberation of halide (Tweel et al. 1987);

3 dioxygenation and subsequent dehydrogenation to halo-substituted dihydroxybenzenes (halocatechols).

For the halocatechol branch, the diversity of the respective "halocatechol precursors" is shown in Figure 2.8.

This mechanistic strategy has been established for chlorobenzoates (Chatterjec et al. 1981; Hartmann et al. 1989; Hartmann et al. 1979; Don et al. 1985; Hickey and Focht 1990; Haller and Finn 1979; Horvath and Alexander 1970; Reineke and Knackmuss 1978a,b) as well as for fluorobenzoates (Engesser et al. 1990b; Hughes 1965; Vora et al. 1988; Horvath and Flathman 1976; Harper and Blakley 1971; Clarke et al. 1975; Ali et al. 1962). In general, the principle of converging pathways allows for one metabolic sequence to operate on substrates as different structurally as halobenzoates, haloacetophenones (Higson and Focht 1990b), halophenoxyalkanoates, haloanilines, halophenols, and halobenzenes.

\section{3-Chlorobenzoate}

A 3-chlorobenzoate(3CB)-utilising bacterium, Pseudomonas sp. B13, was isolated in 1974 after pre-enrichment with benzoate (Dorn et al. 1974). Of all the isomeric monohalobenzoates, this organism utilises only 3-chloro- and 3-bromobenzoate and, after adaptation, 4-fluorobenzoate. Halosubstituted cyclohexadienediol carboxylic acids are formed in an initial dioxygenation step which are dehydrogenated enzymatically to a mixture of 3- and 4-chlorocatechol or 4-fluorocatechol in the degradation, respectively, of 3-chloro- and 4-fluorobenzoate (Reineke and Knackmuss 1978a,b; Dorn and Knackmuss 1978a,b).

\section{(Chlorophenoxy)alkanoates}

Studies on the biodegradation of (2,4-dichlorophenoxy)acctate (2,4-D) and (2-methyl-4chlorophenoxy)acetate (MCPA) likewise showed chlorocatechols as central intermediates for all strains investigated so far. In the first step, the aryl alkyl ether bond is labilised by action of a monooxygenase. The hemiacetals thus generated are chemically unstable, and rearrange to phenols and glyoxylate or homologous $\alpha$-keto acids (Loos et al. 1967a,b,c; Bollag et al. 1967; Tiedje and Alexander 1969; Evans et al. 1971a,b; Gaunt and Evans 1961; Gamar and Gaunt 1971). These substituted phenols are subject to a second monohydroxylation reaction yielding catechols (Bollag et al. 1968; Gaunt and Evans 1971a,b). One representative enzyme for this process, a 2,4-dichlorophenol hydroxylase, has been purified and characterised as highly specific for chlorophenols (Beadle and Smith 1982; Liu and Chapman 1984). Phenol, on the other hand, is not a substrate for this enzyme.

A direct reductive ether cleavage, not in accord with this general reaction scheme, has been described for the transformation of phenoxyalkanoates with long aliphatic chains (MacRae and Alexander 1963) as well as of (2,4,5-trichlorophenoxy)acetate (2,4,5-T) (Mikesell and Boyd 1985). Hydroxylation of the aromatic nucleus prior to ether cleavage was recognised to yield non-degradable products (Faulkner and Woodcock 
1964; Evans et al. 1971a). An Aspergillus niger species was found to totally degrade 2,4-D with climination of chloride before cleavage of the ether bond (Shailubhai $e t$ al. 1983).

As mentioned above, chlorophenols are subject to monohydroxylation yielding chlorocatechols. This transformation can be effected by unspecific phenol hydroxylases (Knackmuss and Hellwig 1978) as well as by highly specialised chlorophenol hydroxylases. Among these, the enzyme coded on the plasmid pJP4 has been shown to strictly prefer 2,4-dichloro- and 2-methyl-4-chlorophenol over monochlorophenols, phenol not being transformed at all (Liu and Chapman 1984; Pieper et al. 1988). The respective enzyme from an Acinetobacter behaved essentially similar. Phenols, although not transformed, acted as uncoupling agents, i.e. caused $\mathrm{H}_{2} \mathrm{O}_{2}$ production from $\mathrm{NAD}(\mathrm{P}) \mathrm{H}$ (Beadle and Smith 1982). The phenomenon of preferential attack of chlorinated compounds over the natural substrate is encountered to a lesser degree also in chlorocatechol degradation.

\section{Chloroanilines}

Chlorinated anilines are transformed to chlorocatechols in a one-step reaction, two hydroxyl groups being inserted geminal and ortho to the amino function by an aniline dioxygenase. The unstable hemi-aminal thus formed eliminates $\mathrm{NH}_{3}$ yielding catechols (Bachofer et al. 1975; Janke et al. 1984). Isomeric halocatechols are produced in varying percentage, depending on the strain employed, from unsymmetrically substituted anilines (Reber et al. 1979; Schukat et al. 1983; Zeyer et al. 1985; Ihn et al. 1989; Janke et al. 1989; Surovtseva et al. 1980; Surovtseva et al. 1986; Latorre et al. 1984; Loidl et al. 1990), as in the case of unsymmetrically substituted halobenzoates (Engesser et al. 1990b). Thus, 2- and 4-chloroaniline are transformed, respectively, to 3-chloro- and 4-chlorocatechol only. From 3-chloroaniline, 4-chlorocatechol is formed preferentially.

\section{Chlorosalicylates}

Chlorosalicylates, like chlorophenols, can be monooxygenated yielding chlorocatechols (Rubio et al. 1986a). Chlorosalicylate-degrading organisms have been constructed by introducing genes encoding a salicylate 1-hydroxylase into a strain with chlorocatechol degrading capacity. Tumover rates vary considerably between the different isomeric chlorosalicylates, with the 3-chloro isomer being the most difficult to degrade (Rubio et al. 1986a,b). Degradation of 3,6-dichloro-2-methoxybenzoic acid (Dicamba) via 3,6dichlorosalicylate was reported, though without any details on the further metabolisation of the halosalicylate.

A Bacillus brevi strain, originally described to degrade 5-chlorosalicylate, was reported to also dissimilate 3,5-dichlorosalicylate (Krueger et al. 1989), 5-chlorosalicylate being proposed as the substrate of a ring-cleaving gentisate 1,2dioxygenase. This would constitute one of the very few cases of direct ring cleavage of chlorosubstituted monohydroxy arenes (not dihydroxyarenes or catechols) (Crawford $e t$ al. 1979). The fact that the 5-chlorosalicylate-degrading Bacillus dissimilates only 3,5-, but not 3,6-dichlorosalicylate indicates that this compound is not degraded via ring cleavage of 3,6-dichlorosalicylate. Rather, transformation of the substrate to a catechol by action of a salicylate monohydroxylase precedes degradation. 


\section{Halobenzenes}

These are metabolised frequently by dioxygenases yiclding halo-substituted dienediols which in turn are dehydrogenated to halocatechols (Reincke and Knackmuss 1984; Sperl and Harvey 1988; Gibson et al. 1968). Di- and trihalobenzenes have also been described to be metabolised via halocatechols (Bont et al. 1986; Meer et al. 1991; Spain and Nishino 1987; Schraa et al. 1986; Oltmanns et al. 1988). Even $o$-dichlorobenzene which is hardly attacked by most haloarene degraders is metabolised by a Pseudomonas strain via initial dioxygenase attack (Haigler et al. 1988). Chlorotoluenes were reported to be degraded despite two mutually "incompatible" substituents on the same aromatic nucleus (see Degradation of Mixtures of Halo and Alkyl Arenes). Degradation of p-chlorotoluene followed the normal chlorobenzene metabolism route, i.e. 2,3-dihydroxylation and formation of both chloro- and methyl-substituted catechols. Subsequently, chlorine is eliminated from the respective muconic acid derivative after cycloisomerisation while the methyl substituent is retained in a methyl-substituted dienelactone (Haigler and Spain 1989). 2,6-Dichlorotoluene degradation was once claimed for a landfill-isolate via a catechol pathway (Vandenbergh et al. 1981) but this preliminary report was not followed up.

The alternative reductive dehalogenation mechanism is discussed later (see Liberation of Halide by Reductive Mechanisms).

\section{Biochemistry of Halocatechol Degradation}

\section{4-Fluorocatechol}

Catechol is degraded in many bacteria along the well-established ortho or 3-oxoadipate pathway (Ornston and Stanier 1966; Ornston 1966). A catechol 1,2-dioxygenase generates cis,cis-muconic acid. This is cycloisomerised to (+)-muconolactone and muconoenollactone which in tum is hydrolyzed to 3-oxoadipate. This is degraded finally to acetyl-CoA and succinate (Fig.2.9).

This mechanism was found to be effective, however, only for the catabolism of 4-fluorocatechol (Clarke et al. 1975; Engesser et al. 1990b; Engesser et al. 1980; Schreiber et al. 1980) which is cleaved, in contrast to other halocatechols, by regular catechol 1,2-dioxygenases at sufficiently high rates to allow growth on 4-fluorobenzoate (Dorn and Knackmuss 1978b; Schreiber et al. 1980). Ring cleavage of halocatechols generally forms the bottleneck of haloarene degradation via ortho pathways. The astonishing reactivity of 4-fluorocatechol can be rationalised in terms of the strong mesomeric electron release of the parafluorine substituent (Engesser $e t$ al. 1988). For all other halocatechols, the inductive electron-withdrawing effect of the halogen drastically decreases reaction rates of the regular oxygen-dependent orthopyrocatechases (Dom and Knackmuss 1978b).

Ortho-cleavage of 4-fluorocatechol yields 3-fluoromuconate which can be smoothly cycloisomerised to 4-fluoromuconolactone (Harper and Blakley 1971). This lactone which, under physiological conditions, is chemically reasonably stable, may be transformed enzymatically by regular enollactone hydrolases to maleylacetate with concomitant formation of fluoride (Schlömann et al. 1990a,b). This pathway is likely to operate also in the Gram-negative strain FLB300 which showed high maleylacetate reductase activity (Engesser et al. 1990b). The reductive step, catalyzed by this enzyme, 


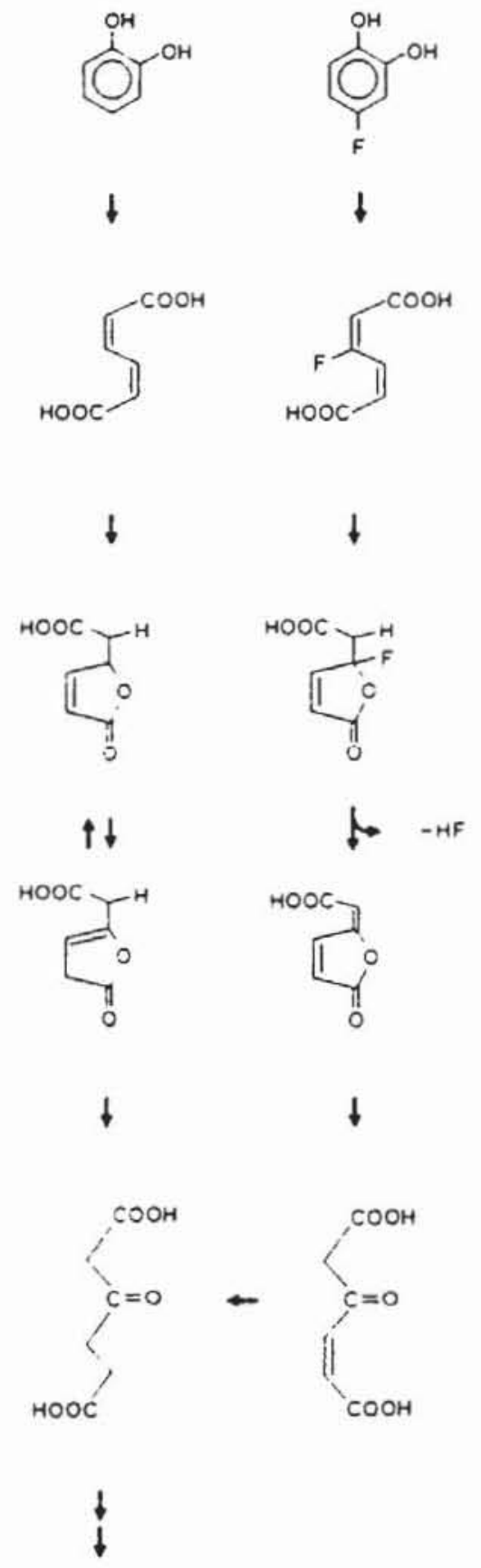

Fig. 2.9. Degradation of catechol and fluorocatechol via the "ortho" pathway.

has the 4-fluorolactone degradation converging with the normal 3-oxoadipate pathway. For dissimilation of 4-fluorocatechol via the ortho pathway, only one additional enzyme is required over that already present in strains degrading catechol via the 3-oxoadipate pathway (see Fig. 2.9). It should be mentioned, however, that in many strains degradation of 4-fluorolactone appears much more complex both as to the enzymes involved and to stability and structure of the transformation products (Schlömann $e t$ al. 1990a,b).

No productive, i.e. growth-sustaining degradation process, for 3-fluorocatechol has been described so far. Either this substrate is hardly transformed at all, or the 2-fluoromuconic acid intermediate is resistant against the cycloisomerases of all 
bacterial sources tested (Engesser et al. 1980; Schmidt and Knackmuss 1980; Schmidt et al. 1980).3-Fluorocatechol thus represents a typical non-biodegradable haloaromatic compound.

Very recently, anaerobic consortia were described to reductively dechlorinate polychlorocatechols to lesser chlorinated derivatives (Allard et al. 1991) (see Liberation of Halide by Reductive Mechanisms). The metabolism of Fluorocatechols, however, was not investigated.

\section{Specialised Enzymes for Halocatechol Catabolism: Three Reasons for Non-biodegradability}

As mentioned above, the simple degradative mechanism for 4-fluorocatechol does not work for 4-chlorocatechol. Firstly, the chlorine substituent severely retards ring cleavage by regular ortho pyrocatechase (Dorn and Knackmuss $1978 \mathrm{~b}$; Engesser et al. 1988). Cycloisomerisation of 3- and especially 2-chloromuconic acid (sec also Fig. 2.10 ) is severely retarded as well since conventional enzymes convert substituted muconic acids only very slowly because of steric hindrance by the rather bulky chlonine and methyl substituents. This illustrates the second major constraint of haloarene catabolism by regular, non-specialised enzymes which often lack the unspecificity to cope with bulky substrates.

The product of 3-chloromuconate cycloisomerisation, unlike 4-fluoromuconolactone (Harper and Blakley 1971; Schlomann et al. 1990b), is chemically unstable and eliminates halide, thus forming a doubly unsaturated lactone (dienclactone) in the final degradative step (Schmidt and Knackmuss 1980). This dienelactone is a dead-end product for which no enzymatic activity is present in any particular bacterium not specialised for halocatechol degradation. Cometabolic degradation of haloarenes thus suffers from a third constraint, the formation of dead-end products.

\section{Halocatechol Degradation via Specialised Ortho Pathway Enzymes}

Halocatechols are intermediates in the degradation of halobenzoates, halobenzenes, haloanilines, halophenols, and other halogenated arenes. These intermediates are effectively degraded by many strains (Dom et al. 1974; Bollag et al. 1968; Pieper et al. 1988; Ditzelmüller et al. 1989; Horvath et al. 1990; Don et al. 1985; Evans et al. 1971a,b). Specialised catechol 1,2-dioxygenases generally attack mono- or dihalogenated catechols, in preference over catechol (Dorn and Knackmuss 1978a,b; Pieper et al. 1988), in an intradiol fashion with formation of substituted muconic acids. Of the various isomeric dichlorocatechols, only 3,5- and 3,6-dichlorocatechol are transformed at excellent rates to, respectively, 2,4- and 2,5-dichloromuconic acid (Pieper et al. 1988; Hartmann et al. 1979; Bont et al. 1986; Spain and Nishino 1987; Schraa et al. 1986). Dioxygenation of 3,4- and 4,5-dichlorocatechols proceeds even slower than with catechol (Pieper et al. 1988; Ditzelmüller et al. 1989; Schraa et al. 1986; Loidl et al. 1990). Further metabolism of the corresponding chloromuconic acids seems to be severely impeded as well. At high biomass concentrations, however, release of chloride indicated a slow albeit productive metabolism (Pieper 1986; Furukawa et al. 1979). 


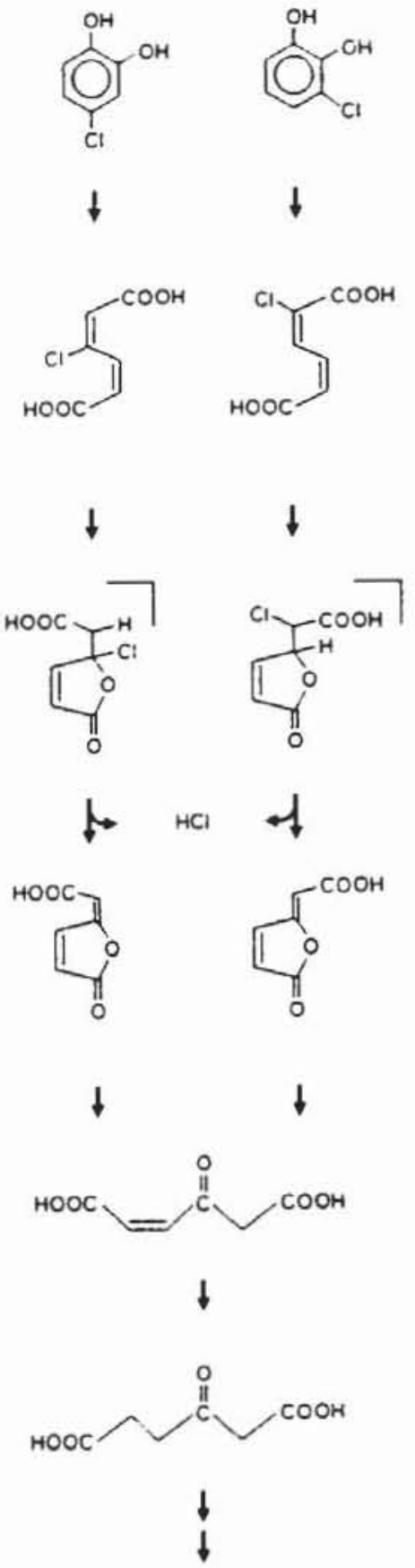

Fig. 2.10. Degradation of chlorocatechols involving cycloisomerisation and spontaneous elimination of hydrogen chloride.

Chlorinated muconic acids are cycloisomerised by more or less specialised chloromuconate cycloisomerases (Schmidt and Knackmuss 1980). Some highly specialised enzymes transform only 2,4-dichloro- and 3-chloromuconic acid at high rates, with 2-chloro- and unsubstituted muconic acid being attacked rather slowly (Pieper et al. 1988; Kuhm et al. 1990).

As shown in Figure 2.10, cycloisomerisation of 2-chloro-cis, cis-muconate affords an unstable butenolide which was proposed to form a doubly unsaturated lactone, trans4-carboxymethylenebut-2-ene-4-olide (trans-dienelactone), by spontaneous anti- 
elimination of hydrogen chloride. Cycloisomerisation of the corresponding 3-chlorocis, cis-muconic acid, upon $\mathrm{HCl}$ elimination, yielded the cis-4-carboxymethylencbut-2en-4-olide (cis-dienclactone) (Schmidt and Knackmuss 1980; Bollag et al. 1968).

This is the first halide liberation step in the course of the ortho pathway. At this point, the degradation pathways of catechol and of the halo analogues are branching mechanistically. Only on the 3-oxoadipate level (see below and Fig. 2.9), the two degradation pathways converge again. The chlorocatechol-related pathways have been shown in some cases, however, to have evolved from the enzymes of regular ortho pathways.

Different muconate cycloisomerases, e.g. chloromuconate cycloisomerase from Pseudomonas putida (pAC27) and dichloromuconate cycloisomerase of Alcaligenes eutrophus JMP134, were shown to be closcly related (Ych et al. 1982; Aldrich et al. 1987; Ghosal and You 1988), and may even have cvolved from common ancestors. This clearly demonstrates nature to be able to cope with new challenges by evolving new activities from pre-existing though inefficient entities. All these enzymes were concluded to follow the same mechanistic pathway, liberating halide from an enzymebonded anionic intermediate instead of eliminating $\mathrm{HCl}$ from the free chloro-substituted cycloisomerisation product (Schlömann et al. 1990)b). Nevertheless, these enzymes should not be mistaken with true halıdohydrolases which actively remove halide by substitution with either hydroxide or glutathione (Goldman et al. 1968).

Enzymes hydrolyzing these dienelactones are termed dienclactone hydrolases. They have been described for many organisms and seem to play an important role in the degradation not only of chloro-, but also of fluoro- and bromoarenes. One enzyme has been purified to homogeneity and characterised by X-ray diffraction (Ngai et al. 1987; Pathak and Ollis 1990; Pathak et al. 1988).

The products of these reactions are maleylacetate or its B-chloro derivative (from 3- and 3,5-dichlorocatechol, respectively). Maleylacetates are readily transformed, by a maleylacetate reductase (MAR), to 3-oxo- or B-ketoadipates whence this pathway was named. The point at which the second chlorine is removed has not yet been established unequivocally. From experiments with an Arthrobacter strain which likewise transforms chlorosuccinate to succinate (Duxburry et al. 1970), it was deduced that chloromaleylacetate is reduced to 2-chloro-4-oxoadipate followed by hydrolysis to acetyl-CoA and chlorosuccinate which in turn yiclds succinatc. Accordingly, ringlabeled (2,4-dichlorophenoxy)acetate was metabolised to succinate (Tiedje et al. 1969). A maleylacetate reductase from a different source was later shown to dehalogenate (B-chloromaleyl)acetate to chloride and 3-oxoadipate, thereby excluding chlorosuccinate as an intermediate in 3,5-dichlorocatechol degradation. The authors reported that chloromaleylacetate reduction required twice as much NADH as malcylacetate turnover. They concluded that the product of maleylacetate reductase action, chloro-substituted B-ketoadipate, spontaneously eliminated chloride to maleylacetate which in a second step was reduced to 3-oxoadipate. There remains some doubt as to this mechanism since no purified enzymes were employed. It is doubtful, for instance, whether 2chloro-4-oxoadipate in fact is sufficiently unstable to spontaneously eliminate chloride, forming maleylacetate. Nevertheless, chlorocatechol degradation can be considered as clearly established from the work on 3-chlorobenzoate and (2,4-dichlorophenoxy)acetate degradation in the last 25 years.

The pathways, detailed above, allow for metabolisation of mono- and dihalo catechols. There is no indication, however, that the enzymes involved can productively metabolise tri- or even more heavily substituted halocatechols. Polychlorinated aromatic substrates with $\geq 3$ chlorine atoms per ring therefore must be metabolised via 
different routes. Two exceptions to this rule have recently been proposed. For 1,2,4trichlorobenzene (1,2,4-TCB), aerobic transformation via 3,4,6-trichlorocatechol and subsequent metabolisation along a specialised ortho pathway was suggested (Meer $\mathrm{et}$ al. 1991). The authors could not exclude the possibility of initial oxygenolytic chloride release (sec Oxygenolytic Elimination of Halogen), and did not present any evidence on what happened to the third chlorine of the 1,2,4-TCB substrate. Likewise, aerobic degradation of 1,2,4,5-tetrachlorobenzene has been reported to proceed via chlorocatechols (Springer and Rast 1988; Wittich et al. 1989). Once again, one cannot exclude initial dechlorination prior to ring cleavage via 3,5,6-trichlorocatechol as an intermediate.

\section{Degradation of Mixtures of Halo and Alkyl Arenes}

The metabolism of halocatechols via so-called meta pathways as a rule is unproductive, resulting in production of dead-end metabolites, slow and non-stoichiometric liberation of halide, and inactivation of the key enzymes, the catechol-2,3-dioxygenases (Bartels et al. 1984; Engesser et al. 1989a) (for the only exception reported so far, see Dehalogenation of Halocatechols after Meta-Cleavage). This situation still holds today despite many efforts (Engesser KH, unpublished results; Pfeiffer F, personal communication). Alkylcatechols, on the other hand, are generally degraded by enzymes of the meta pathway. Metabolism via ortho-cleavage as a rule leads to accumulation of methyllactones as dead-end metabolites (Engesser et al. 1989a). Mixtures of halo- and alkylcatechols therefore cannot be degraded quantitatively since the pathways for these two substrates are mutually incompatible. All efforts have failed so far to isolate bacteria which can productively degrade halocatechols via meta pathways, i.e. not in a comctabolic manner. A new selection technique was therefore developed to identify microorganisms with modified ortho pathways. From enrichment experiments with methyllactones, methylcatechol-degrading organisms were isolated which, preferentially or even exclusively, utilise ortho pathways for complete mineralisation of halo and alkyl arene mixtures. The meta-cleaving enzyme was inactivated by transposon insertion to avoid misrouting of halocatechols. Alternatively, enzymes of the methylcatechol ortho pathway were cloned into strains, free of meta pathways (Engesser et al. 1989a).

This gocs to show that non-biodegradability of otherwise easily metabolisable compounds may also be due to misrouting of substrates. Very recently, a Pseudomonas strain was described to degrade a mixture of chlorobenzene and toluene (Pettigrew et al. 1991). Chloro- and methylcatechols were found to be accumulated in the culture medium; this did not happen with a mutant of this strain which had been blocked in the gene encoding the meta-pyrocatechase enzyme. Both methyl- and chlorocatechol were metabolised via an ortho pathway.

\section{Oxygenolytic Elimination of Halogen}

It has becn shown in the chapters above that metabolism of haloarenes via halocatechols and subsequent ortho cleavage is a useful tool in microbial degradation of these compounds. Such ortho-cleaving routes are restricted, however, to mono- and disubstituted halocatechols. Even these compounds may be rendered slowly 


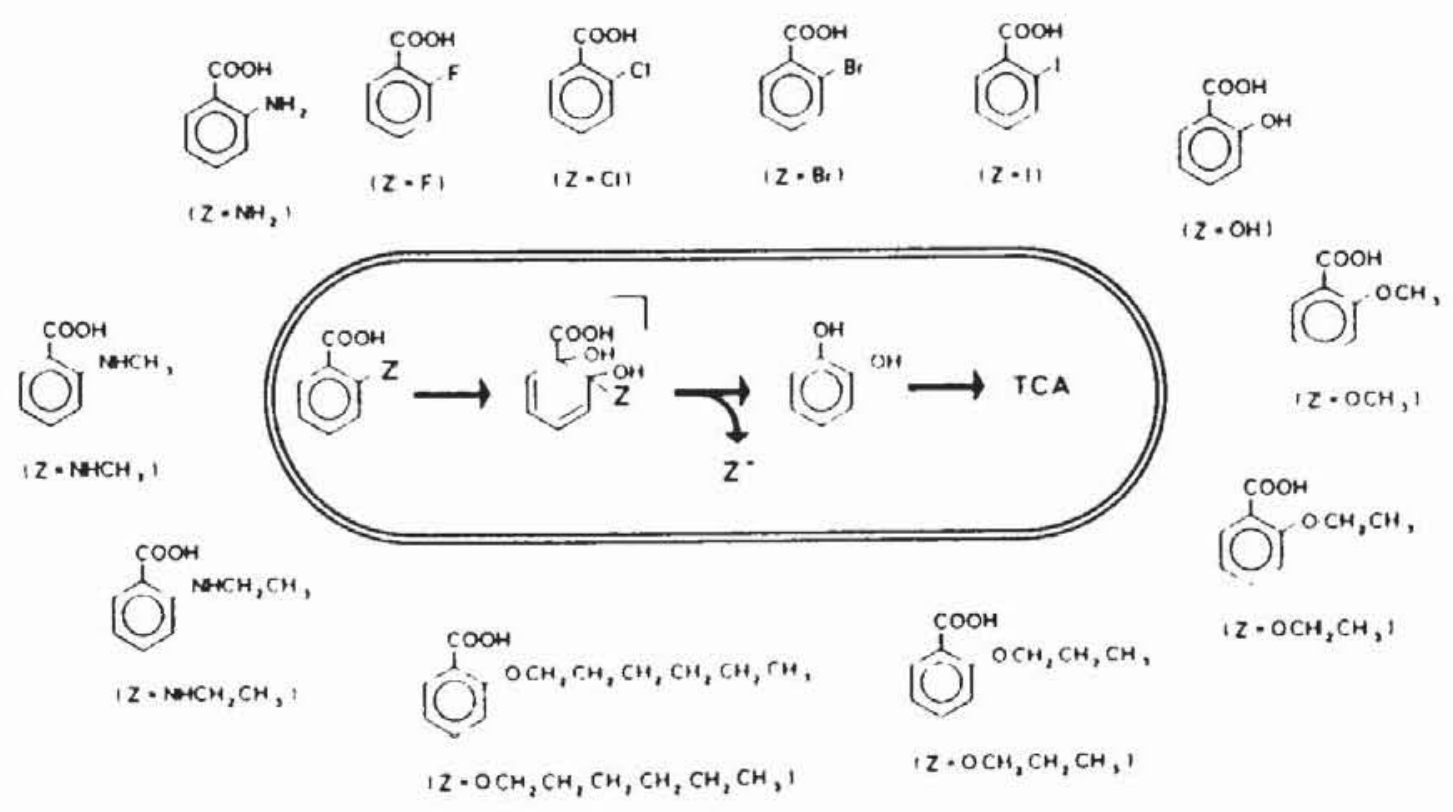

Fig. 2.11. Degradation of vanous aromatic substrates by initial dioxygenation in Pseudomonas puuda CL.B 250.

biodegradable by unfavourable substitution patterns, e.g. vicinal dihalo substitution. Biomineralisation therefore is greatly facilitated if some mechanism exists by which halo substituents are eliminated at an early metabolic stage.

2-Fluoro- and 2-chlorobenzoate are frequently employed as model substrates for oxygenolytic substituent removal. Dioxygenase attack yields geminal halohydroxy compounds which spontaneously rearomatise to unsubstituted catechol, with concomitant liberation of halide (Engesser et al. 1980; Hickey and Focht 1990; Engesser and Schulte 1989; Vora el al. 1988). This oxygenolytic mechanism apparently also works for 2-bromo- and, after some mutation, for 2-iodobenzoate (Engesser and Schulte 1989). The halogen-free catechols thus formed are further metabolised along ortho pathways. The 1,2-dioxygenation mechanism was established unequivocally by analysis of the 2 -methylbenzoate cometabolism products. For degradation of 2-chlorobenzoate by Pseudomonas sp. strain B300, however, oxygenolytic elimination of halide was not confirmed with certainty, and a degradation pathway via 3-chlorocatechol could not be definitely excluded (Sylvestre et al. 1989).

Interestingly, the 2-chlorobenzoate-degrading enzyme system in Pseudomonas sp. CLB 250 (Engesser and Schulte 1989) proved to be functional also for various other 2-substituted benzoates with substituents which may be eliminated as anions (see Fig. 2.11), e.g. alkoxy, amino, and alkylamino groups. Dioxygenases thus could be demonstrated to effectively cleave ether molecules. This capacity was extended even to the degradation of halogenated dibenzofurans and dibenzodioxins (see Strategies for Degradation of Chlorinated Dibenzofurans and Dibenzodioxins).

Fluoride elimination from 3,5-difluoro-4-hydroxybenzoate, with accumulation of 5-fluoro-3,4-dihydroxybenzoate (5-fluoroprotocatechuate), was effected by the monooxygenating 4-hydroxybenzoate-3-hydroxylase of Pseudomonas fluorescens (Husain et al. 1980). Dehalogenation of 3-substituted fluorobenzenes by a toluene dioxygenase has recently been reported (Renganathan 1989); this rather unspecific enzyme at the same time produced varying amounts of fluorocatechols, however, depending on the size of the substituent in 3-position. 


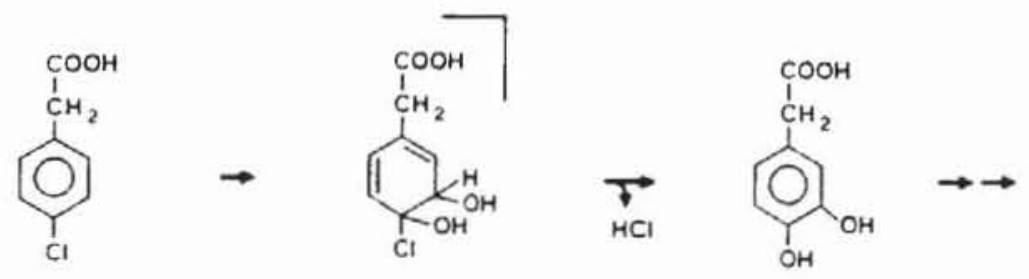

Fig. 2.12. Degradation of 4-chlorophenyl acetate by a Pseudomonas species strain CBS 3 .

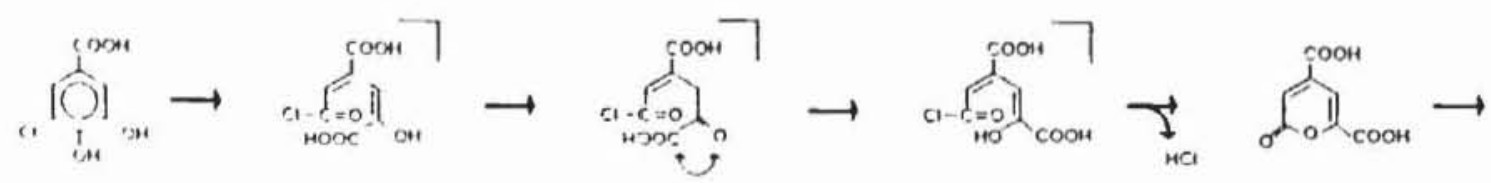

Fig. 2.13. Bacterial dehalogenation of 5 chlorovanillate.

A Pseudomonas sp. strain CBS3 has been suggested to dioxygenate 4-halophenyl acctates to unstable cis-dihydrodiols (Klages et al. 1981; Markus et al. 1984) which, after rearomatisation and elimination of halide, afforded homoprotocatechuate (see Fig. 2.12). The two enzyme components catalyzing the dehalogenation were purified, and the reaction was demonstrated to require $\mathrm{NADH}$ and $\mathrm{Fe}^{2+}$. No final proof for a dioxygenation mechanism was presented, however, e.g. by product analysis of unproductive alkyl-analogue turnover or by employing mixtures of ${ }^{18} \mathrm{O}_{2} /{ }^{16} \mathrm{O}_{2}$. The homoprotocatechuate formed is metabolised via another meta pathway.

\section{Dehalogenation of Halocatechols after Meta Cleavage: the 5-Chlorovanillate Case}

In the course of the bacterial catabolism of lignin model compounds, 5-methoxyvanillate was transformed into 5-methoxyprotocatechuate, and the methoxy substituent then removed in the course of the dioxygenation catalyzed by a protocatechuate 4,5-dioxygenase (Kersten et al. 1985). Surprisingly, the chlorine in 5-chlorovanillate is removed analoguously after ring cleavage of 5-chloroprotocatechuate (see Fig. 2.13), with a pyrone being formed (2-pyrone-4,6dicarboxylate). Dehalogenation seems to be gratuitous in this case; it may offer a tool, though, for the evolution of new dehalogenating enzymes from ether-cleaving oxygenases. There are indications, on the other hand, that chloride is eliminated from 4-chlorobenzoate in the first metabolic step of a 4-carboxybiphenyl ether-cleaving dioxygenase (Engesser et al. 1990a). As yet, the productive meta-cleavage of halocatechol derivatives, described above, has rarely been found in nature, and seems to be restricted to ortho-halosubstituted catechols.

Consequently, $30 \%$ only of the organic halogen was released as halide (measured reliably by a halogen electrode) in the course of cometabolism of the 4-halocatechols produced from 4-chloro- and 4-fluorobenzoate by Pseudomonas putida mt-2. A chlorinated semialdehyde was characterised extensively, and the proximal mode of ring 
cleavage established unequivocally for 4-halocatechols (Schacht et al. submitted for publication). Slow cometabolic degradation via meta pathway was claimed for 4chlorocatechol derived from 4-chlorophenol, with $85 \%$ of the stoichiometric amount of halide reputedly being released. Halide detection was based on a spot test, though, and could not be reproduced in our laboratory with the original strain. Also, no ringcleavage products were characterised (Janke and Fritsche 1979).

Chloro-substituted products of chlorocatechol ring cleavage accumulated in the culture broth during degradation of 1- and 2-chloronaphthalin (Morris and Barnsley 1982). The authors speculated about the toxicity of these compounds without any firm structural data. No growth was observed with chloronaphthalenes, and chloride release was not measured.

Despite many efforts, a productive, i.e. growth-sustaining metabolism of halogenated catechols vic meta pathways has not been verified so far. Cometabolic liberation of halide, however, may occur to varying extent.

\section{Strategies for Degradation of Chlorinated Dibenzofurans and Dibenzodioxins}

Chlorinated dibenzofurans and dibenzodioxins are among the most pernicious chemicals. Up to now, no single microorganism has been found which was able to degrade higher chlorinated dibenzofurans or dibenzodioxins. In devising a strategy for rendering these recalcitrant molecules biodegradable, it is essential to dissect the tricyclic compounds into individual structural elements such as the biarylether linkage and the vicinal dichloro-substitution pattern. Some knowledge has been accumulated in the last few years on the degradation of 1,2-dichloroarenes (Meer et al. 1991; Haigler et al. 1988; Allard et al. 1991). Little information is found in the literature on degradation of biaryl ethers in general, and of cyclic biaryl ethers in particular. Efforts have been concentrated, therefore, on the microbial, especially bacterial degradation of biaryl ethers. Once the two isolated problems have been resolved, the single degradative capabilities must be combined either in a single strain or in a mixed culture; this has been shown a useful tool in biodegradation (Engesser et al. 1989a).

As described above, few competent model systems existed for the dioxygenolytic cleavage even of alkyl aryl ethers (Kersten et al. 1982), and none for diaryl ethers (Engesser and Schulte 1989). In the meantime, dioxygenolytic ether cleavage surprisingly has been realised even with cyclic biarylethers. Degradation of 3- and 4-carboxybiphenylether (CBPE) (Wittich 1990; Engesser et al. 1990a) is triggered by initial 1,2-dioxygenation, shown by isolation and unequivocal characterisation of deadend products of ether analogues (Engesser et al. 1990a). Dioxygenase attack on aryl ether bonds yields chemically labile hemiacetals which, in the case of CBPE, decompose to protocatechuate and phenol both of which are easily biodegradable. This clearly demonstrates the superiority of an early cleavage of those bonds, constituting the xenobiotic structure, over cleavage at a later stage.

Dibenzofuran- and dibenzodioxin-attacking bacteria have been described quite recently (Engesser et al. 1989b; Fortnagel et al. 1990). A detailed investigation of the DBF metabolism revealed initial dioxygenolytic cleavage of the aryl ether bond once again to be the crucial step in the overall degradation (Engesser et al. 1989b). The product of dibenzofuran ether cleavage, 3-(2-hydroxyphenyl)catechol (HPC), was shown to suffer 

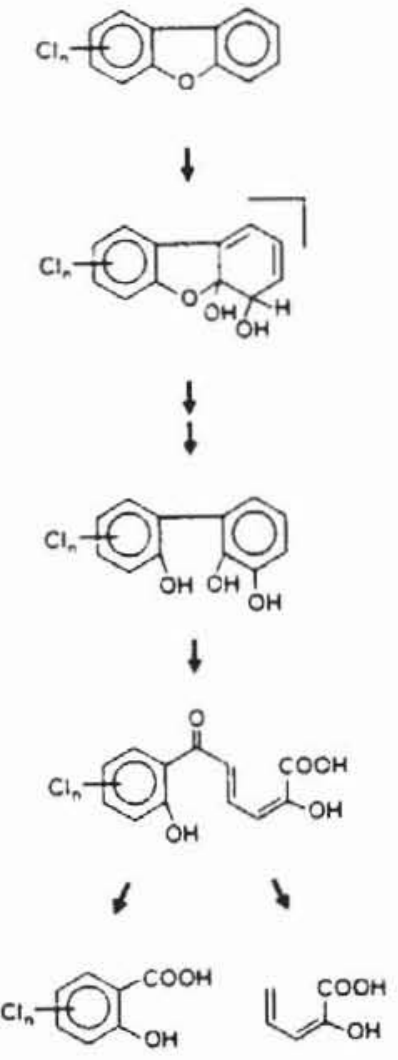

Fig. 2.14. Degradation of chlorinated dibenzofuran ethers by bacteria.

meta cleavage (Strubcl et al. 1991). In an ensuing step, hydrolase activity produces salicylate and 2-oxo-4-pentenoate, with the same pathway being proposed for chlorinated analogues (Fig. 2.14). Unsubstituted salicylate is metabolised via catechol which then is cleaved in meta fashion and subsequently degraded by enzymes of the meta pathway; the same mechanism holds for the oxopentenoate metabolite. Recently, oxidation of 2-chloro- and 2,8-dichloro-DBF has been claimed (Parsons et al. 1990) without, however, establishing the biochemistry of the process.

Even though degradation of dibenzodioxin and its chlorinated analogues is complicated by the second ether bond, organisms have been described which effectively transform the parent compound (Harms et al. 1990). Mono-, di-, and, to a limited extent, trihalogenated DBDs were already shown to be metabolised substantially by several bacterial species, pre-grown on dibenzofuran. No products, however, were given (Rast et al. DBP 1989). There clearly is a pressing need for research in this field in order to identify bacteria which are able to effectively degrade dibenzodioxins and finally the chloro derivatives. The extremely limited "bioavailibility" of these compounds may have to be overcome by applying two-phase systems. 


\section{Hydrolytic Displacement of Halogen}

\section{Chlorobenzoates}

Hydrolytic liberation of halide, at an early stage of the overall metabolism, greatly enhances the biodegradability of the target compounds, as in the case of the oxygenolytic removal of halosubstituents. Such hydrolytic dechlorination was first shown with an Aspergillus niger strain transforming 2-chloro- to (2-hydroxyphenoxy)acetate (Faulkner and Woodcock 1961). Later, degradation of 3-chlorobenzoate via 3-hydroxy-and 3,6-dihydroxybenzoate (gentisate) was described (Johnston et al. 1972), which definitely proceeded without any chlorocatechol production. The stoichiometry of 3-hydroxybenzoate excretion and substrate turnover was not determined, however, and the proposed hydrolytic mechanısm of chloride substitution could not be established unequivocally.

In the following period, many different cases of hydrolytic halogen removal were presented. In one case, hydrolytic liberation of halide from 4-chlorobenzoate was reported even for alkalophilic conditions (Shimao et al. 1989). Besides 4-fluorobenzoate (Oltmanns et al. 1989), 4-chlorobenzoate was frequently employed as substrate; it is dechlorinated by various Arthrobacter (Ruisinger et al. 1976; Marks et al. 1984b), Nocardia (Klages and Lingens 1979), Pseudomonas (Klages and Lingens 1980), Acinetobacter (Adriaens et al. 1989; Adriaens and Focht 1991), and Alcaligenes species (Tweel et al. 1986). If, in the degradation by Alcaligenes, oxygen concentration was reduced to $1.2 \%$ of the normal saturation concentration, accumulation of 4-hydroxybenzoate was observed which the authors had suggested as the direct product of hydrolysis. No definite proof was given, though, for the hydrolytic and nonoxygenolytic nature of halide liberation, e.g. by ${ }^{18} \mathrm{O}$-labeling experiments. In all the transformations described so far, 4-hydroxybenzoate was metabolised first to 3,4-dihydroxybenzoate which then was degraded along either ortho (Klages and Lingens 1980) or meta pathways (Ruisinger et al. 1976; Klages and Lingens 1979).

Incorporation of ${ }^{18} \mathrm{OH}$, from ${ }^{18} \mathrm{O}$-labeled $\mathrm{H}_{2} \mathrm{O}$, definitely proves that dehalogenation proceeds as a hydrolytic process (Müller et al. 1984; Marks et al. 1984a). No ${ }^{18} \mathrm{O}$ label was incorporated into the 4-hydroxybenzoate formed in a negative control experiment under incubation with ${ }^{18} \mathrm{O}_{2}$ gas (Marks et al. 1984a). The enzyme from Pseudomonas CBS3 (Klages and Lingens 1980) in crude extracts was found to be activated by $\mathrm{Mn}^{2+}$ and $\mathrm{Co}^{2+}$. In contrast to the enzyme from Arthrobacter, 4-fluorobenzoate could not be converted (Thiele et al. 1987). The polar or even ionic carboxyl group seems to be requisite for substrate binding (Thiele et al. 1988) since methyl 4-chlorobenzoate was not a substrate. Cloning experiments at first seemed to indicate that more than one gene was involved in 4-chlorobenzoate hydrolysis (Savard et al. 1986); recently, it was demonstrated that, in a first step, the 4-chlorobenzoate is transformed to the CoA ester which is the effective substrate for the action of a regular molecular-weight hydrolase (Loffler et al. 1991). The key step accordingly is a nucleophilic attack at the chlorosubstituted C-4 carbon atom of the 4-chlorobenzoate CoA-ester (sce Fig. 2.15).

A recent report (Adriaens and Focht 1991) on the mechanism of hydrolysis of the aryl chloro bond, based on results of the 3,4-dichlorobenzoate transformation by an Acinetobacter strain 4-CB1, may be interpreted in favour of an addition-elimination mechanism (see Fig. 2.16). In a first step, the para-Cl is replaced by $\mathrm{OH}$. Water then is added in 3,4-position followed by elimination of $\mathrm{HCl}$. Subsequent enzymatic processes 


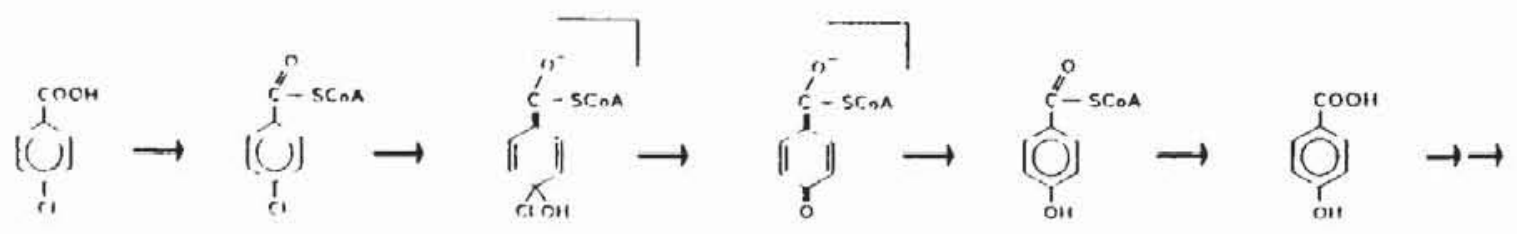

Fig. 2.15. Chloroarene dehalogenation mechanism involvıng nucleophilic attack at the chlorosubstututed $\mathrm{Cl}$ atom.

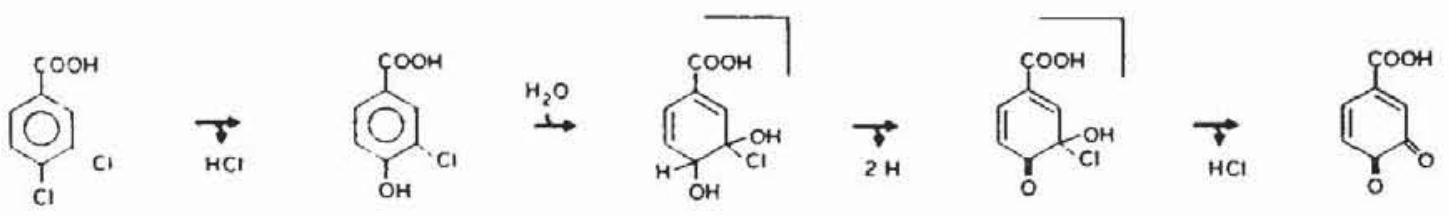

Fig. 2.16. Addition-elımination mechanism for the hydrolysis of the aryl chloro bonds in 3,4dichlorobenzoate.

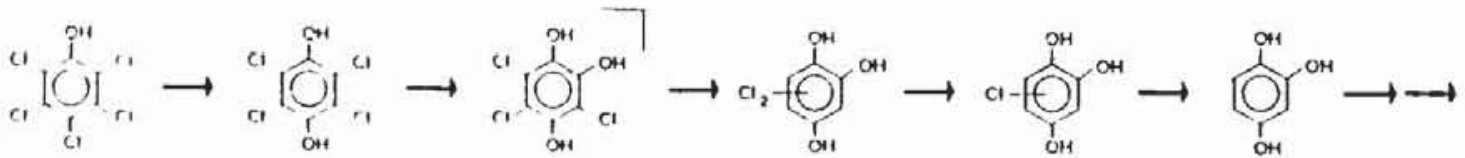

Fig. 2.17. Hydrolyuc degradation of pentachlorophenol involving two substitition and three reducuve dehalogenation steps.

yield 4-carboxy-o-quinone which may be the product of anaerobic cometabolism of 3,4-dichlorobenzoate by the 4-chlorobenzoate-grown cells. No matter which enzymatic mechanism actually prevails, the aromatic $\pi$ system of the chloroarene substrate has to be broken up prior to hydrolysis of the carbon-halogen bond.

A combination of reductive and hydrolytic attack was reported for 2,4-dichlorobenzoate (Zaitsev and Karasevich 1985; Tweel et al. 1987), the initial product of reductive dechlorination, 4-chlorobenzoate, being metabolised via hydrolytic halide replacement (see Liberation of Halide by Reductive Mechanisms). For a Pseudomonas aeruginosa strain, recently reported to dehalogenate 2-bromobenzoate, hydrolytic displacement of halogen is indicated by accumulation of salicylate in oxygen-depleted cells (Higson and Focht 1990a).

\section{Pentachlorophenol (PCP}

For hydrolytic pentachlorophenol (PCP) degradation (Häggblom et al. 1989; Apajalahti and Salkinoja-Salonen 1987), initial substitution of chlorine by $\mathrm{OH}$ to 2,3,5,6tetrachlorohydroquinone was proposed, a second substitution step yielding 3,5,6trichloro-1,2,4-trihydroxybenzene (see Fig. 2.17). Further degradation proceeded via three reductive dehalogenation steps (see Liberation of Halide by Reductive Mechanisms). The hypothesis that the $p$-chlorine substituent is displaced hydrolytically 
not only in pentachlorophenol but also in 2,3,4,5- and 2,3,4,6-tetrachlorophenol, seems to be confirmed by labeling experiments with $\mathrm{H}_{2}{ }^{18} \mathrm{O}$ for which ${ }^{18} \mathrm{O}$-labelled hydroquinone intermediates were established (Apajalahti and Salkinoja-Salonen 1987). However, the hydrolytic displacement reaction worked only in the presence of NADH; additionally, at least traces of oxygen were required. This prompted other researchers to carefully re-examine the first dechlorination step in the Arthrobacter strain ATCC 33790 (Schenk et al. 1989; Schenk et al. 1990). Labeling experiments with $\mathrm{H}_{2}{ }^{18} \mathrm{O}$ and ${ }^{18} \mathrm{O}_{2}$, as possible oxygen donors, revealed that para- ${ }^{18} \mathrm{OH}$ groups were introduced only when the enzyme extract was incubated with $\mathrm{NADH} / \mathrm{O}_{2}$ as ${ }^{18} \mathrm{OH}$ equivalents. However, since the ${ }^{18} \mathrm{OH}$ label was also non-enzymatically incorporated into tetrachlorohydroquinone from $\mathrm{H}_{2}{ }^{18} \mathrm{O}$, no differentiation is possible between hydrolytic and oxygenolytic removal of halogene. These results, i.e. the requirement for oxygen and a reduced pyridine dinucleotide being present, allow the assumption that the first step in PCP degradation is an oxygenolytic attack also for the Rhodococcus strain (see Apajalahti and Salkinoja-Salonen 1987). Interestingly, PCP degradation potential seems to be rather wide-spread, having been demonstrated for many bacteria (Rott et al. 1979; Saber and Crawford 1985; Suzuki 1977; Watanabe 1973; Liu et al. 1981; Klecka and Maier 1985; Pignatello et al. 1983). A Flavobacterium sp. has becn demonstrated to also attack triiodophenols after growth on PCP (Xun and Orser 1991).

\section{$N$-Heterocycles}

s-Triazines which are widely used as herbicides have been described to be biodegradable in both acrobic and anacrobic systems (Cook and Hütter 1981; Jessce et al. 1983). These compounds, just as some chlorinated derivatives like 6-amino-2-chloro-4ethylamino-1,3,5-triazine, serve as source of nitrogen. Since the transformation was carricd out anacrobically in cell extracts, the authors concluded the dehalogenation to follow a hydrolytic mechanism. Degradation was triggered by removal of the chlorine substituent, yielding 2-amino-4-cthylamino-1,3,5-triazine-6(5H)-one. Two dehalogenases have been proposed which differ in specificity towards the two alkylamino functions in these triazine agrochemicals (Cook and Hütter 1986). The subject of s-triazine degradation is covered in an excellent review (Cook 1987).

In the breakdown of 5-chloro-2-hydroxynicotinic acid, a dead-end product of 3-chloroquinoline-8-carboxylic acid partial degradation (see Channelling of Complex Haloarene Structures into Key Intermediates), chloro-substituted maleic or fumaric acid were proposed as intermediates which in turn are subject to hydrolytic dehalogenation (Tibbles et al. 1989b).

\section{Liberation of Halide by Reductive Mechanisms}

Molecular oxygen was initially considered to be essential for the activation of arencs by hydroxylation. Non-activated benzene derivatives, with three or more halogen substituents, would be expected, from simple mechanistic considerations, to be more or less non-biodegradable by enzymes which employed an electrophilic hydroxylation mechanism. Unexpectedly, polyhalophenols were found to still be degraded in acrobic systems, most probably by action of monooxygenating enzymes. This seemed to invalidate the "dogma" that heavily chloro-substituted arenes are not subject to acrobic 
microbial attack. One might argue, however, that the electrophilic displacement of the first chlorine substituent in polyhalophenols is facilitated by the mesomeric effect of a para-hydroxyl group. This is exemplified e.g. by the formation of tetrachloro- $\rho$ hydroquinone from pentachlorophenol discussed above (Häggblom et al. 1989; Apajalahti and Salkinoja-Salonen 1987).

Still more surprisingly, dioxygenolytic liberation of chloride from tetrachlorobenzenes was claimed in two cases (Springer and Rast 1988; Wittich et al. 1989). These substrates are deactivated towards electrophilic attack by four chlorines without the remedy of an activating $\mathrm{OH}$-substituent. The situation is problematical, though, only as long as an electrophilic mechanism of hydroxylation is assumed; for a possible attack by radical species, these objections would no longer hold.

Dehalogenation of an aromatic nucleus was reported even in the absence of oxygen (Ide et al. 1972; Kuwatsuka and Igarashi 1975; Murthy et al. 1979). Accumulation of lesser chlorinated phenols like 2,3,5- and 2,4,5-tri-, 3,4-di- and 3-chlorophenol from pentachlorophenol indicated a reductive mechanism of chlorine removal without additional hydroxylation steps. Many reductive dehalogenation reactions have been described since these early reports, e.g. for pesticides such as techlofthalam (Kirkpatrick et al. 1981), thiobencarb (Moon and Kuwatsuka 1984), chlornitrofen (Yamada and Suzuki 1983), 2,4,5,6-tetrachloroisophthalonitrile (Sato and Tanaka 1987), and diuron (Attaway et al. 1982; Stepp et al. 1985). Partial metabolism was observed in many cases, with only one chlorine atom being removed and lesser chlorinated metabolites being accumulated.

Polyhalophenols are metabolised, after initial attack presumably by monohydroxylases (Apajalahti and Salkinoja-Salonen 1987), by hydrolytic as well as reductive processes, with complete liberation of the organic halogen as halide. A cell frec extract of a Rhodococcus species (Häggblom et al. 1989) was found to catalyze formation of 1,2,4-trihydroxybenzene from 2,3,5,6-tetrachlorohydroquinone (see Fig. $2.16)$, following a reductive mechanism. This same mechanism seems to operate in the degradation of 2,3,5,6-tetra-, 2,3,6- as well as 2,4,6-tri-, and 2,6-dichlorophenol by a Flavobacterium species isolated with pentachlorophenol as a selection substrate. The dehalogenation enzymes preferentially dehalogenate 2,6-disubstituted halophenols (Steiert et al. 1987).

Purely reductive dechlorination systems have been described in addition to the combined action of hydrolytic/oxygenolytic on one, and reductive dechlorination systems, on the other hand. Partial dechlorination of pentachlorophenol to lesser chlorinated phenols was found to depend on pre-enrichment with monochlorophenols (Mikesell and Boyd 1986). A combination of these enrichment cultures could be demonstrated to totally dehalogenate pentachlorophenol, with some formation of methane. For pentachlorophenol, uniformly labeled with ${ }^{14} \mathrm{C}, 70 \%$ of the radioactive carbon was recovered in form of ${ }^{14} \mathrm{CO}_{2}$ and ${ }^{14} \mathrm{CH}_{4}$.

Aquatic sediments were found to liberate halogen from mono- and dichlorophenols (Sharak-Genthner et al. 1989a), 4-chlorophenol generally being degraded with the slowest rate. Degradation of 3- and 4-chlorobenzoate in some cases was nitratedependent, suggesting nitrate respiration as the energy-providing process (SharakGenthner et al. 1989b). A 2-chlorophenol-mineralising anaerobic mixed culture was isolated from sewage sludge which dehalogenated also 2-bromo- and 2,6-dichlorophenol reductively. 2,4-Dichlorophenol in this system was transformed only to 4-chlorophenol which once again proved to be hardly degradable under anaerobic conditions (Dietrich and Winter 1990). Recently, however, 2,4-dichlorophenol was 


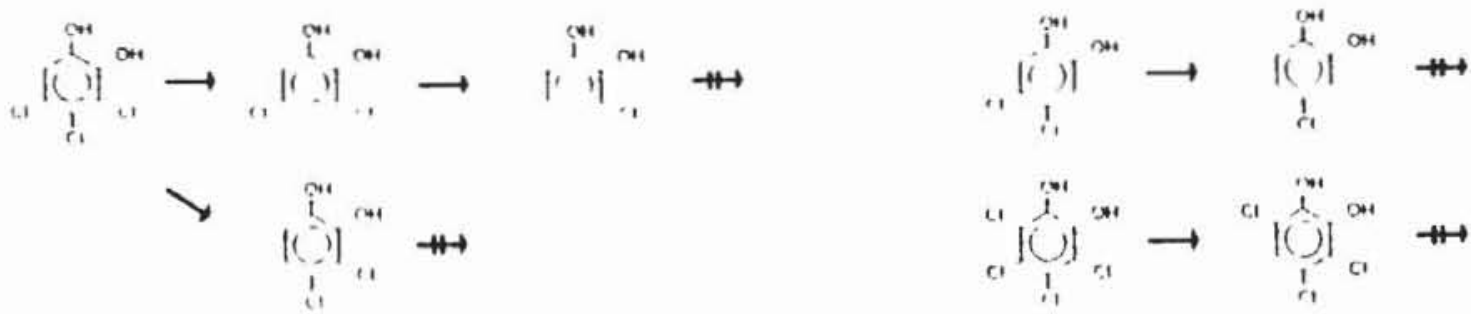

Fig. 2.18. Anaerobic dechlonnation of chlonnated catechols.

demonstrated to be totally dechlorinated via 4-chlorophenol and phenol; this finally was carboxylated to benzoate (Zhang and Wiegel 1990).

A 2,4-dibromophenol-degrading consortium was described, without commenting on the energetics of the dehalogenation step (King 1988), which consists of dehalogenating organisms and sulfate-reducing bacteria. The latter did not directly attack the halophenol but rather utilised the dehalogenated phenol.

Quite recently, a rare case of anacrobic dechlorination was reported for chlorinated catechols, i.e. 1,2-dihydroxybenzenes (Allard et al. 1991). Cultures enriched with vanillins, catechin, and phloroglucinol as substrates exhibited dechlorinating activity with chloro catechols. The process is highly specific, yielding, for example, exclusively 3-chlorocatechol from 3,4,5-trichlorocatechol. Chloride removal was observed also with other isomeric chlorocatechols as shown in Figure 2.18.

Anacrobic transformation of 3-bromo-4-hydroxyben/aldehyde to 4-hydroxybenzoate and, ultimately, phenol has been described to be catalyzed by cultures enriched from sediments (Neilson et al. 1988).

A rare case of phototrophic metabolism of 3-chlorobenzoate (3CB) was recorded for Rhodopseudomonas palustris WSI7 (Kamal and Campbell-Wyndham 1990). Of the radioactive label from 3-chlorobenzoate, $75 \%$ was incorporated into the biomass, $25 \%$ being liberated as ${ }^{14} \mathrm{CO}_{2}$. The authors claimed chloride release to occur during reductive degradation of the cosubstrate, benzoate, without presenting any detailed evidence, however, for this pathway.

Biotransformation of polyhalogenated biphenyls probably represents the most important instance of reductive dehalogenation. As described above (sce Channelling of Complex Haloarene Structures into Key Intermediates), acrobic metabolism of polychlorinated biphenyls (PCBs) frequently leads to accumulation of chlorinated intermediates which may be bound chemically to soil components (Brunner et al. 1985) thus feigning total degradation. Intensive dehalogenation, prior to acrobic metabolism, would render PCBs much more susceptible to total breakdown into $\mathrm{CO}_{2}$ and chloride, the ultimate goal of biodegradation. Sediments from the Hudson River, New York, were investigated for anacrobic degradation potential towards PCBs. Mono- and dichlorinated biphenyls were degraded most efficiently, biphenyls with four or more chloro substituents were not. Trihalogenated biphenyls were transformed only when the chlorine substituents were scattered over both rings; 2,3-dichloro substitution, for example, strongly reduced transformation rates (Chen et al. 1988).

Other investigators found, however, that even Arochlor $1260^{R}$, with an average of six chlorine atoms per molecule, was attacked in Hudson river sediments. Since different patterns of lesser chlorinated PCBs were formed, different microbial consortia seemed to participate in these transformations. Dehalogenation reactions were clearly biological, no significant chemical reduction taking place (Brown (jr.) et al. 1987). In a separate investigation, dechlorination of Arochlor $1242^{\mathrm{R}}$ was demonstrated at a 

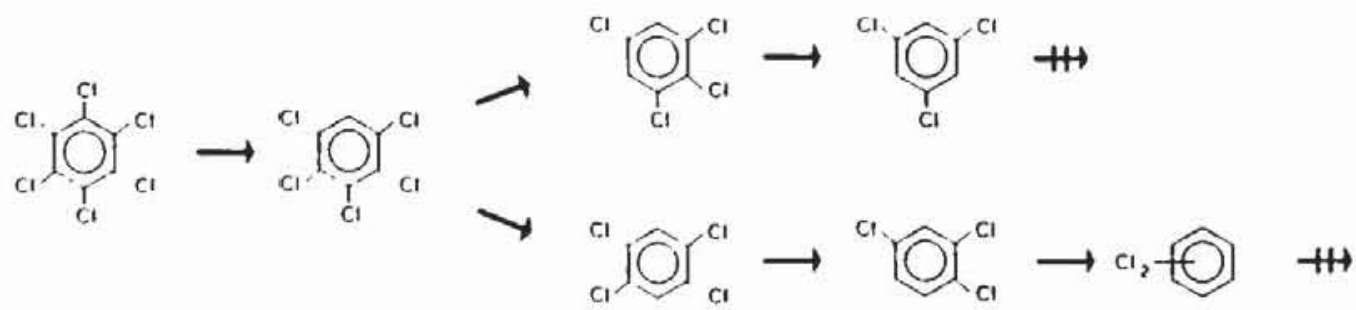

Fig. 2.19. Reductuve dechlorination of hexachlorobenzene.

concentration of as high as $700 \mathrm{mgl}^{-1}$ sediment. Within 16 weeks, half of the organic chlorine was metabolised, with the percentage of mono- and dichloro biphenyls increasing from $9 \%$ to $88 \%$. The para and meta chlorines were displaced preferentially (Quensen (III) et al. 1988). Arochlor ${ }^{R} 1260$, in contrast, proved to be more recalcitrant, and in laboratory degradation experiments required far longer adaptation times. After one year, only $15 \%$ of the meta and para chlorines had been removed. Lesser chlorinated biphenyls again proved to be very susceptible to reductive dechlorination in these systems (Quensen(III) et al. 1990).

Reductive dechlorination by microorganisms has been described also for hexachlorobenzene (Fig. 2.19). The final products, 1,3,5-tri- and isomeric dichlorobenzenes, were not transformed further; penta- and tetrachlorobenzenes, however, were accumulated only transiently (Fathepure et al. 1988). Different organisms, in soil columns, were shown to reductively dechlorinate tri- and dichlorobenzenes to chlorobenzene as the final metabolite (Bosma et al. 1988). These dechlorination reactions seem to be mediated by rather unspecialised enzymes since bacteria of many different species, isolated from intestine and not previously exposed to haloarenes, were able to catalyze dechlorination of 1,2,4-trichlorobenzene to chlorobenzene (Tsuchiya and Yamaha 1984). As enzymatic reactions, these dehalogenations still show considerable specificity. Another hexachlorobenzenedegrading consortium was shown to accumulate 1,2,3- and 1,2,4-tri- as well as 1,3- and 1,2-dichlorobenzene (Mousa and Rogers 1990). Partial dechlorination of hexachlorobenzene by glutathione addition has been demonstrated for mammals, pentaand tetrachlorobenzene being formed besides 2,3,5,6-tetrachlorophenylmethylmercaptan (Renner and Nguyen 1984).

Halosubstituted anilines have also been described to be dehalogenated reductively. For example, 2,4- and 3,4-dichloroaniline are transformed to monochloroanilines. These dichloroaniline-transforming cultures degrade 3,4-dichlorophenol without any lag phase; thus, cross acclimation seems to have taken place between phenol- and anilinetransformation processes (Struijs and Rogers 1989). 2,3,4,5-Tetrachloroaniline was reductively dechlorinated to 2,3,5-tri- and 3,5-dichloroaniline (Kuhn and Suflita 1989) (Fig. 2.20); the principle that chlorine substituents in ortho or para position to an electron-releasing group are removed preferentially, seems to hold also for anilines.<smiles>Nc1cc(Cl)cc(Cl)c1</smiles>

Fig. 2.20. Reductive dehalogenation of chlorosubstituted anslines. 


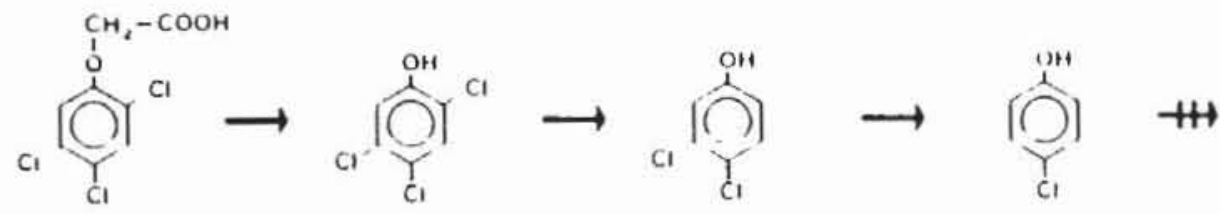

Fig. 2.21. Cleavage of the aryl alkyl ether bond and subsequent reductive dechlorination of chlonnated phenoxyacetate.

In pond sediments, reductive dechlorination of Diuron ${ }^{R}$ (3,4-dichlorophenyl-1,1dimethylurea) in 4-position yielded 3-chlorophenyl-1,1-dimethylurea in stoichiometric amount (Attaway et al. 1982). Structurally related herbicides also suffer reductive dehalogenation (Stepp et al. 1985).

Chlorinated phenoxyacetates were demonstrated to be reductively dechlorinated after cleavage of the aryl alkyl ether bond. A 3-chlorobenzoate-enriched consortium selectively substituted the para-chlorine in 2,4,5-T (2,4,5-trichlorophenoxyacetate), yielding (2,5-dichlorophenoxy)acetate (Suflita et al. 1984). 2,4,5-T, after cleavage of the ether bond and removal of the ortho chlorine, was transformed to 3,4-dichlorophenol in anacrobic sewage sludge. Further removal of the meta chlorine resulted in the accumulation of 4-chlorophenol which could not be degraded further (Mikescll and Boyd 1985) (sce Fig. 2.21).

A 3- and 4-chlorobenzoate-degrading consortium was found to degrade the halobenzoates anacrobically, inevitably requiring nitrate. The authors speculated about a reductive dechlorination of haloben\%oates to ben\%oate which in turn was proposed to be degraded with nitrate as an electron acceptor (Sharak-Genthner et al. 1989a).

A reductive dechlorination of DDT (1,1,1-urichloro-2,2-bis(4-chlorophenyl)ethane) was reported to be catalyzed by a Pseudomonas aeruginosa strain (sec Channelling of Complex Haloarene Structures into Key Intermediates).

There is only scattered knowledge on the mechanism of reductive dechlorination reactions despite their tremendous potential for bioremediation of contaminated sites. One crucial question is whether the microorganisms can derive energy from the dehalogenating reaction and thus may be kept in pure culture.

The best studied model system is the dehalogenation of 3-halo-substututed benzoates (Suflita et al. 1982; Horowitz et al. 1983). For a 3-chlorobenzoate-degrading consortium, the individual organisms were separated, and a strain DCB-1 was recognised as principal dechlorinating organism (Shelton and Tiedje 1984). It could be shown from thermodynamic calculations that the reductive dechlorination step in strain DCB-1 is exergonic, supplying energy to the cell by a novel type of chemotrophic mode of growth (Dolfing 1990; Mohn and Ticdje 1990).

Degradation of 2-fluorobenzoate by benzoate-dissimilating, denitrifying bacteria was reported (Schennen et al. 1985). When cells were grown anaerobically on benzoate, they transformed 2-fluorobenzoate without any lag period, under concomitant defluorination. A benzoyl-CoA-synthetase, the key enzyme especially of anacrobic benzoate degradation, was demonstrated to be active also towards 2-fluorobenzoate. The authors speculated about fortuitous elimination of fluoride from reduced intermediates, no clear-cut evidence, however, being presented for the reductive nature of the defluorination mechanism. This holds also for the anacrobic defluorination of 2- and 4-fluorobenzoate, catalyzed by other denitrifying bacteria (Taylor et al. 1979).

In general, however, the exact mechanism of reductive dechlorination remains uncertain. The reaction may, for one, proceed in form of direct substitution by hydride. 
Alternatively, a two-step process may be envisaged, e.g. by substitution of halogen by a hydroxyl group which would have to be followed by reductive dehydroxylation. The fact that reductive dehalogenation is an energy-yielding process would eventually be met also by an intermediate dehydroxylation step which from calculations was estimated to be an energy-conserving reaction (Szewzyk et al. 1985). An especially attractive mechanism would follow the addition-climination process analoguous to that discussed for the hydrolytic removal of halogen by haloarene hydrolases (see Hydrolytic Displacement of Halogen and Figure 2.16) (Adriaens and Focht 1991)). Further indepth investigations are definitely necessary to clarify this issue. Although the first step in reductive transformation of benzene derivatives generally is strongly endergonic (Evans and Fuchs 1988), the overall reaction may be exergonic due to the elimination of halide.

\section{Conclusions}

An important application of HAH biodegradation is bioremediation, i.e. the clean-up of polluted environmental compartments by microbiological methods. On-site trials have shown pentachlorophenol (PCP) to be amenable to biodegradation, with PCP concentration being reduced from $200 \mathrm{mg} \mathrm{kg}^{-1}$ to $15 \mathrm{mg} \mathrm{kg}^{-1}$ soil upon addition of a Rhodococcus species (Valo and Salkinoja-Salonen 1986). Soil contaminated with 2,4,5-T (2,4,5-trichlorophenoxyacetate) was decontaminated after supplementation with a Pseudomonas strain, the herbicide concentration being reduced from an initial $20 \mathrm{~g} \mathrm{~kg}^{-1}$ to $1-2 \mathrm{~g} \mathrm{~kg}^{-1}$ soil (Kilbane et al. 1983). In these cases, organisms were available which derived energy from the biodegradation processes. Transformation of polychlorinated biphenyls (PCBs), in contrast, seems not to yield energy, and thus does not sustain growth. To overcome this limitation, unsubstituted biphenyl was added to soil heavily contaminated with PCBs. Thus, the cometabolic transformation potential was enhanced considerably although still no total degradation was observed (Brunner $e t$ al. 1985).

The generally very lipophilic HAHs tend to be absorbed on soil particles (Sabljic 1989). Therefore, the "bioavailability", i.e. the accessibility of these substrates for microorganisms otherwise very competent for degradation, is severely reduced. Addition of emulsifiers or of organic phases (Viney and Bewley 1990; Brink and Tramper 1985) may greatly improve degradation efficiency (Harvey et al. 1990). Alternative microorganisms were described producing their own bioemulsifiers (Ramsay et al. 1988; Morgan and Watkinson 1989). Research on and application of bioremediation techniques is nicely covered by a recent review (Morgan and Watkinson 1989).

Biodegradation can effectively aid in clcan-up of contaminated soils and aquifers. To overcome its limitations, microbiology, biochemistry, chemistry, genetics, and process enginecring must collaborate in developing microorganisms with improved degradative capacities when natural evolution does not produce the desired activities.

\section{Acknowledgement}

We thank H-J Knackmuss for many fruitful discussions during preparation of this review. The help of $\mathrm{H}$ Runge with aquisition of literature is greatfully acknowledged as is that of $\mathrm{C}$ Kauffmann in typing the manuscript. 


\section{References}

Adnaens P. Focht DD (1991) Cometabolism of 3,4-dichlorobenzoate by Acinetobacter sp. strain 4.CB1. Appl Environ Microbiol 57(1):173-179

Adnaens P. Kohler H.PE., Kohler-Staub D, Focht DD (1989) Bactenal dehalogenation of chlorobenzoates and coculiure biodegradation of 4.4'dichlorobiphenyl Appl Environ Microbiol 55(4):887-892

Adriaens P, Focht DD (1990) Contınuous coculture degradatıon of selected polychlorinated biphenyl congeners by Acinetobacter spp. in an aerobic reactor system. Environ Sci Technol $24(7) \cdot 1042$. 1049

Ahmed M. Focht DD (1973) Degradation of polychlorinated biphenyls by two species of Achromobacier Can J Microbiol 19:47.52

Aldrich TL, Frantz B, Gill JF, Kubane JJ, Chakrabarty A.M (1987) Cloning and complete nucleotide sequence determination of the catB gene encoding cis,cis-muconate lactonising enzyme. Gene 52:185-195

Alı DA, Callely AG. Hayes M (1962) Ability of a vibrio grown on benzoate to oxidise parafluorobenzoate. Nature 196194.195

Allard A.S. Hynning P.A. Lindgren C. Kemberger M, Neilson All (1991) Dechlonnation of chlorocatechols by stable ennchment cultures of anacrobic bactena Appl Environ Microbiol $57(1) .77 .84$

Apajalahtı JHA, Salkınoja-Salonen MS (1987) Dechlorination and para-hydroxylation of polychlonnated phenols by Rhodococcus chlorophenolicus J Bactenol 169(2) 675-681

Attaway HH, Camper ND, Paynter MJB (1982) Anacrobic microbial degradation of Diuron by pond sediment. Pest Bıochem Physiol 17.96-101

Bachofer R, Lingens F. Schafer W (1975) Conversion of aniline into pyrocalechol by a Nocardia sp incorporatuon of oxygen-18. FEBS l.etl 50 288-290

Ballschmiter K, L'nglen KC. Neu HT (1977) Abbau von chlorierten Aromaten. Mikrobiologischer Abbau der polychlonenen Bıphenyle(PCB) III. Chlonerte Benzoesauren als Metaholite der PCB. Chemosphere 1:51.56

Banels I, Knackmuss H-J, Reineke W (1984) Suicıde inaciıvation of catechol 2,3-dioxygenase from Pseudomonas putida mi-2 by 3-halocatcchol. Appl Environ Microbiol 47:500-505

Baxier RA, Gilbert PE, Lidgett RA. Mainprize JH, Vodden HA (1975) The degradation of polychlorinated biphenyls by microorganisms. Sci Total Einviron 4:53-61

Beadle CA. Smith ARW (1982) The punfication and properties of 2,4-dichlorphenol hydroxylase from a strain of Acinetobacter species. Fur J Microbiol 123323.332

Bedard DL, Linterman R. Bopp L.H. Brennan MJ, Haberl ML., Johnson C (1986) Rapid assay for screening and characterising microorganisms for the ability 10 degrade polychlorinated biphenyls. Appl Environ Microbiol 51(4).761.768

Bedard DL. Ilaberl ML. May RJ. Brennan MJ (1987) Evidence for novel mechanisms of polychlonnated biphenyl metabolism in Alcaligenes eutrophus 11850. Appl Environ Microbiol 53(5):1103.1112

Behret H (1989) Eintrag in die L'mwelt bei Herstellung. Verarbeitung. Verwendung und Abfallbeseiugung. In 2,4-Dichlor phenol. Beratergremium fur umweltrelevante, Altstoffe (ed) vol 4, VCH Verlagsgesellschaft, Weinheim, pp 8-19

Bollag J-M, Helling CS, Alexander M (1967) Metabolism of 4-chloro-2-methylphenoxyacetic acid by soil bactena. Appl Microbiol 15:1393.1398

Bollag J-M, Hellıng CS, Alexander M (1968) 2,4-D metabolısm. Enzymatic hydroxylation of chlonnated phenols. J Agnc Food Chem 16:826-828

Bont Jan AMde, Vorage Marc JAW, Hartmans Sybe. Tweel Will JJvan den (1986) Microbial degradation of 1,3-dichlorobenzene. Appl Environ Microbiol 52(4):677-680

Bosma TNP. Meer JR van der, Schraa G, Tros ME, Zehnder AJB (1988) Reductive dechlonnation of all tnchloro- and dichlorobenzene isomers. FEMS Microbiol Ecol 53:223.229

Brink LES, Tramper J (1985) Optumisation of organic solvent in muluphase biocatalysis. Biolechnol Bioeng 27:1258-1269

Brown(jr.) JF, Bedard DL, Brennan MJ, Camahan JC. Feng H, Wagner RE (1987) Polychlorinated biphenyl dechlonnation in aquatıc sediments. Science 236:709.712

Brunner W, Sutherland FII, Focht DD (1985) Enhanced biodegradation of polychlonnated biphenyls in soil by analog enrichment and bactenal inoculation. J Environ Qual 14(3):324-328 
Bursc VW, Head SL, Korver MP, McClure PC, Donahue JF, Needham LL (1990) Determination of selected organochlorine pesticides and polychlorinated biphenyls in human serum. J Anal Toxicol 14(5/6):137-142

Catelanı D, Sorlını C. Treccanı V (1971) The metabolısm of biphenyl by Pseudomonas putida. Experientıa 27:1173-1174

Chattergee DK, Kellog ST, Hamada S, Chakrabarty AM (1981) Plasmid specifying total degradatuon of chlonnated benzoic acids. J Bacteriol 146:639-646

Chen M, Hong CS, Bush B, Rhee G-Y (1988) Anaerobic biodegradation of polychlorinated biphenyls by bacteria from Hudson river sediments. Ecotoxicol Environ Safety 16:95-105

Clarke KF, Callely AG, Livingstone A, Fewson CA (1975) Metabolism of monofluorobenzoates by Acinetobacter calcoaceticus N.C.I.B. 8250. Biochım Bıophys Acta 404:169-179

Colluns GB, Holmes DC, Hoodless RA (1982) Organochlonne pesticide residues in human milk in Great Britain, 1979-80. Human Toxicol 1:425-431

Commandeur L.CM. Parsons JR (1990) Degradatıon of halogenated aromatic compounds. Biodegradation 1:207-220

Cook AM (1987) Biodegradation of s-Inazune xenobiotıcs. FEMS Microbiol Rev 46:93-116

Cook AM. Hutter R (1981) s-Triazines as nitrogen sources for bacteria. J Agric Food Chem 29:1135-1143

Cook AM. Hutter R (1986) Ring dechlorination of deethylsimazine by hydrolases from Rhodococcus corallinus FEMS Microbiol Lelt 34:335-338

Crawford Ronald I., OIson PE, Frick TD (1979) Catabolısm of 5-chlorosalicylate by a Bacillus isolated from the Mississippi nver. Appl Environ Microbiol 38(3):379-384

Dagley S (1978) Pathways for the utulisation of organic growth substrates. In: Gunsalus LC (ed) The Bactena, Vol. VI Bacterial Diversity, vol 5, Academic Press Inc., New York, pp 305-388

Dietrich G, Winter J (1990) Anaerobic degradation of chlorophenol by an enrichment culture. Appl Microbiol Biotechnol 34-253-258

Ditzelmuller G, Loidl M, Streichsbier F (1989) Isolation and characterisation of a 2,4dichlorophenoxyacetıc acid-degrading soil bactenum. Appl Microbiol Biotechnol 31:93-96

Dolfıng Jan (1990) Reducuve dechlonnation of 3-chlorobenzoate is coupled to ATP production and growth in an anacrobic bacterium, strain DCB-1. Arch Microbiol 153:264-266

Don RH, Weightman AJ, Knackmuss H-J, Timmis KN (1985) Transposon mutagenesıs and cloning analysis of the pathways for degradation of 2,4-dichlorophenoxyacetic acid and 3-chlorobenzoate in Alcaligenes eutrophus JMP134(pJP4). J Bacteriol 161:85-90

Dom E, Knackmuss H-J (1978a) Chemical structure and biodegradability of halogenated compounds. Two catechol 1,2-dioxygenases from a 3-chlorobenzoate-grown pseudomonad. Biochem J 174:73-84

Dom E, Knackmuss H-J (1978b) Chemical structure and biodegradability of halogenated aromatic compounds. Substıtuent effects on 1,2-dioxygenation of catechol. Biochem J 174:85-94

Dom E, Hellwig M, Reineke W, Knackmuss H-J (1974) Isolation and characterisation of a 3-chlorobenzoate degrading pseudomonad. Arch Microbiol 99:61-70

Durham Don R, Stewart David B (1987) Recruitment of naphthalene dissimilatory enzymes for the oxıdation of 1,4-dichloronaphthalene to 3,6-dichlorosalicylate, a precursor for the herbicide Dicamba. J Bacteriol 169(6):2889-2892

Duxburry JM, Tiedje JM, Alexander M. Dawson JE (1970) 2.4-D metabolism: enzymatic conversion of chloromaleylacetıc acid to succinic acid. J Agnc Food Chem 18:199-201

Engesser K-H, Schulte P (1989) Degradation of 2-bromo-, 2-chloro- and 2-fluorobenzoate by Pseudomonas putida CLB250. FEMS Microbiol Lett 60:143-148

Engesser K-H, Schmıdt E, Knackmuss H-J (1980) Adaptation of Alcaligenes eutrophus B9 and Pseudomonas sp. B13 to 2-fluorobenzoate as growth substrate. Appl Environ Microbiol 39:68. 73

Engesser K.H, Caın RB, Knackmuss H.J (1988) Bacterial metabolism of side chain fluorinated aromatıcs: cometabolısm of 3-trifluoromethyl(TFM)benzoate by Pseudomonas putida (arvilla) mL2 and Rhodococcus rubropertinclus N657. Arch Microbiol 149:188-197

Engesser KH, Pıeper DH, Rojo F. Timmis KN, Knackmuss H-J (1989a) Simultaneous degradation of chloro- and methylaromatics via ortho pathway by genetically engineered bacteria and natural soil isolates. In: Hattori T, Ishida Y, Maruyama Y, Monta RY, Uchida A (eds) Recent advances in microbial ecology, Japan Scientific Societies Press, Tokyo, pp 622-626

Engesser KH, Strubel V, Christoglou K, Fischer P, Rast HG (1989b) Dioxygenolytic cleavage of aryl ether bonds: 1,10-dihydro-1,10-dihydroxyfluoren-9-one, a novel arene dihydrodiol as evidence for angular dioxygenation of dibenzofuran. FEMS Microbiol Lett 65:205-210 
Engesser KH, Fietz W. Fischer P. Schulte P. Knackmuss H1-J (1990a) Dioxygenolyıc cleavage of aryl ether bonds: 1,2-Dihydro-1,2-dihydroxy-4-carboxybenzophenone as evidence for initial 1,2. dioxygenation in 3-and 4-carboxy biphenylether degradation. FEMS Microbiol l.ett 69:317-322

Engesser KH, Aulıng G, Busse J, Knackmuss H-J (1990b) 3-Fiuorobenzoate ennched bactenal strain FLB 300 degrades benzoate and all three isomenc monofluorobenzoates. Arch Microbiol 153:193.199

Evans WC, Smith BSW, Femley HN, Davis JI (197la) Bacterial metabolism of 2.4-dichlorophenoxyacetate. Biochem J 122:543-551

Evans WC. Smith BSW, Moss P. Fernley HN (1971b) Bacterial metabolism of 4-chlorophenoxyacetate. Biochem J 122:509.517

Evans WCh, Fuchs G (1988) Anacrobic degradation of aromatic compounds. Ann Rev Microbiol 42:289-317

Fathepure BZ., Tiedje J.M. Boyd SA (1988) Reductive dechlonnation of hexachlorobenzene to in and dichlorobenienes in anaerobic sewage sludge. Appl Einviron Microbiol 54:327-330

Faulkner JK, Woodcock D (1961) Fungal detoxication. V. Metabolism of o- and p-chlorophenoxyaceuc acids by Aspergillus niger J chem Soc:5397-5400

Faulkner JK. Woodcock D (1964) Metabolism of 2,4-dichlorophenoxyacetic acid (2,4-D) by Aspergillus niger Nature 203865

Focht DD, Alexander M (1970) Bacterial degradation of diphenylmethanc, a DDT model substrate Appl Microbiol $20608-611$

Focht DD, Alexander M (1971) Aerobic cometabolism of DI)T analogues by Hydrogenomonas sp J Agnc Food Chem 19.20-22

Focht DD. Brunner W (1985) Kinetics of biphenyl and polychlonnated biphenyl metabolism in soil. Appl Environ Microbiol 50(4)-1058-1063

Fortnagel P, Harms H, Wituch R-M. Krohn S, Meyer H, Sinnwell V. Wilkes H, Francke W (1990) Metabohism of ditenzofuran by Pseudomonas sp strain 111169 and the mixed culture 11127 . Appl Environ Microbiol 56(4):1148-1156

Frank R. Braun IIE (1989) PCB and DDE residues in milk supplies of Ontano, Canada 1985-1986 Bull Environ Contam Toxicol 42.666-669

Frommer W, Kanne R. Neupert M, Rasi H-G, Springer W, Tillman W (1990) Mikrobieller Abhau von mehrfach halogenierten Aromaten. Patent application No 90105412.2 Bayer AG (applicant)

Furukawa K, Matsumura F (1976) Microbial metabolism of polychlonnated biphenyls. Studies on the relative degradability of polychlonnated biphenyl components by Alcaligenes sp. J Agnc Food Chem 24:251-256

Furukawa K. Matsumura F. Tonomura K (1978) Alcaligenes and Acınetobacter sirains capable of degradıng polychlorinated biphenyls. Agnc Bıol Chem 42.543.548

Furukawa K. Tomizuka N. Kamibayashı A (1979) Eiffect of chlonne substitution on the bacterial metabolism of various polychlonnated biphenyls. Appl Finviron Microbiol 38:301-310

Furukawa K. Tomizuka N, Kamsbayashı A (1983) Mctabolic breakdown of Kanechlors (polychlorobiphenyls) and their products by Acinetobacter sp.. Appl Environ Microbiol 46(1): 140.145

Gamar Y. Gaunt JK (1971) Bacterial metabohsm of 4-chloro-2-methylphenoxyacetatc formation of glyoxylate by side-chain cleavage. Bıochem J 122:527-531

Gaunt JK, Evans WC (1961) Metabolısm of 4-chloro-2-methylphenoxyacetic acid by a soil microorganısm. Biochem J 79:25-26

Gaunt JK. Evans WC (1971a) Metabolism of 4-chloro-2-methylphenoxyacetate by a soil pseudomonad. Preliminary evidence for the metabolıc pathway. Biochem J 122:519-526

Gaunt JK. Evans WC (1971b) Metabolism of 4-chloro-2-methylphenoxyacetate by a soil pseudomonad Ring-fission, lactonising and delactonising enzymes. Biochem J 122:533-542

Ghosal D. You I-S (1988) Nucleotide homology and organisation of chlorocatechol oxidation genes of plasmids pJP4 and pAC27. Mol Gen Genet 211:113-120

Ghosal D. You I-S, Chatterjee DK. Chakrabarty AM (1985) Microbial degradation of halogenated compounds. Science 228(4696):135-142

Gibson DT, Koch JR, Schuld CL, Kallı RE (1968) Oxidative degradation of aromatic hydrocarbons by microorganisms. II. Metabolism of halogenated aromatic hydrocarbons. Biochemistry 7:3795-3802

Goldman P, Milne GWA, Keister DB (1968) Carbon-halogen bond cleavage. III. Studies on bacterial halidohydrolases. J Biol Chem 243:428-434

Golovleva LA, Skryabin GK (1981) Microbial degradatıon of DDT. In: Leisinger T, Hutter R, Cook AM, Nüesch J (eds) Microbial degradation of xenobıotics and recalcitrant compounds, vol FEMS Symposium No. 12, Academic Press, New York, PP 287.291 
Hagenmater H (1986) Determınation of 2,3,7,8-tetrachlorodibenzo-p-dioxin in commercial chlorophenols and related products. Fresenius $Z$ Anal Chem 325:603-606

Haggblom MM (1990) Mechantsms of bacterial degradation and transformation of chlorinated monoaromatic compounds. J Basic Microbıol 30(2):115-141

Haggblom MM. Nohynek LJ. Salkinoja-Salonen MS (1988) Degradation and o-methylation of chlonnated phenolic compounds by Rhodococcus and Mycobacterium strains. Appl Environ Microbiol 54: 3043-3052

Haggblom MM, Janke D, Salkınoja-Salonen MS (1989) Hydroxylatıon and dechlorination of tetrachlorohydroquinone by Rhodococcus sp. strain CP-2 cell extracts. Appl Environ Microbiol 55(2):516-519

Haigler BE, Spain JC (1989) Degradation of $\rho$-chlorotoluene by a mutant strain of Pseudomonas sp. strain JS6 Appl Finviron Microbiol 55:372-379

Haigler BF: Nishino SF, Spain JC (1988) Degradation of 1,2-dichlorobenzene by a Pseudomonas sp. Appl Environ Microbiol 54:294-301

Haller HD, Finn RK (1979) Biodegradation of 3-chlorobenzoate and formation of black colour in the presence and absence of ben soate. Furopean J Appl Microbiol 8:191-205

Harms H, Wittich R-M. Sinnwell V, Meyer H, Fortnagel P. Francke W (1990) Transformation of dibenzo- $\rho$-dioxın by Pseudomonas sp. strain H1169. Appl Environ Microbiol 56:1157-1159

Harper DB. Blakley ER (1971) The metabolism of $\rho$-fluorobenzoic acid by a Pseudomonas sp.. Can J Microbiol 17:1015-1023

Hartmann J, Reineke W, Knackmuss H-J (1979) Metabolısm of 3-chloro-, 4-chloro-, and 3,5dichlorobenzoate by a pseudomonad. Appl Environ Microbiol 37:421-428

Hartmann J, Engelberts K, Nordhaus B, Schmidt E, Reineke W (1989) Degradation of 2-chlorobenzoate by in vivo constructed hybrid pseudomonads. FEMS Microbiol Lett 61:17-22

Harvey S, Elashvili I, Valdes JJ, Kamely D. Chakrabarty AM (1990) Enhanced removal of Exxon Valdez spilled ol from Alaskan gravel by a microbial surfactant. Bı-Technology 8(3):228-230

Hickcy WJ, Focht DD (1990) Degradation of mono-, di-, and trihalogenated benzoic acids by Pseudomonas aerugınosa JB2. Appl Environ Microbiol 56(12):3842-3850

Higson FK, Focht DD (1990a) Degradation of 2-bromobenzoic acid by a strain of Pseudomonas aeruginosa Appl Environ Microbiol 56(6):1615-1619

Higson FK, Focht DD (1990b) Bacterial degradation of ring-chlonnated acetophenones. Appl Environ Microbiol 56(12)·3678-3685

Hill DL, Phelps TJ, Palumbo AV, White DC, Strandberg GW, Donaldson TL (1989) Bioremediation of polychlorinated biphenyls: Degradation capabilities in field lysımeters. Appl Biochem Biotechnol 20/21:223-243

Horowitz A, Suflita JM, Tiedje JM (1983) Reductive dehalogenation of halobenzoates by anaerobic lake sediment microorganisms. Appl Environ Microbiol 45(5):1459-1465

Horvath M, Ditzelmuller G, Loidl M, Streichsbier F (1990) Isolation and characterisation of a 2-(2,4-dichlorophenoxy) propionic acid-degrading soil bacterium. Appl Microbiol Biotechnol 33:213-216

Horvath RS, Alexander M (1970) Cometabolism of $m$-chlorobenzoate by an Arthrobacter. Appl Microbiol 20(2):254-258

Horvath RS, Flathman P (1976) Co-metabolism of fluorobenzoates by natural microbial populations. Appl Environ Microbiol 31(6):889-891

Horvath RS (1971) Comctabolism of the herbicide 2,3,6-trichlorobenzoate. J Agric Food Chem 19(2):291-293

Hughes DE (1965) The metabolism of halogen-substututed benzoic acids by Pseudomonas fluorescens. B1ochem J 96:181-188

Husain M, Entsch B, Ballou DP. Massey V, Chapman P (1980) Fluoride elımination from substrates in hydroxylation reactions catalyzed by $\rho$-hydroxybenzoate hydroxylase. J Biol Chem 255(9):4189.4197

Ide A, Niki Y, Sakamoto F Watanabe 1, Watanabe H (1972) Decomposition of pentachlorophenol in paddy soil. Agric Biol Chem 36(11):1937-1944

Ihn W, Janke D, Tresselt D (1989) Cntical steps in degradation of chloroaromatics by Rhodococci III. Isolation and identification of accumulating intermediates and dead-end products. J Basic Microbiol 29:291-297

Ip HMH, Phillıps DJH (1989) Organochlorine chemicals in human breast milk in Hong Kong. Arch Environ Contam Toxicol 18(4):490-494

Janke D, Fritsche W (1979) Dechlorierung von 4-Chlorphenol nach extradioler Ringspaltung durch Pseudomonas putida. Z allg Mikrobiol 19(2):139-141 
Janke D, Baskunov BP. Nefedova MYu, Zyakun A.M. Golovleva LA (1984) Incorporatuon of ${ }^{18} \mathrm{O}_{2}$ duning comctabolic degradation of 3-chloroaniline by Rhodococcus sp. An 117. \% allg Mikrobol 24:253-259

Janke D. Ihn W. Tresselt D (1989) Cntical steps in degradation of chloroaromatics by Rhodococc IV. Detailed kınetics of substrate removal and product formation by resting pre-adapted cells J Basic Microbiol 29(5)·305.314

Jessee JA, Benoit RE, Hendncks AC, Allen GC, Neal Jl. (1983) Anaerobic degradation of cyanunc acid, cysteine, and Atrasın by a facultative anaerobic bacterium. Appl Environ Microbiol 45(1):97.102

Johnson BT. Kennedy JO (1973) Biomagnification of p.p'-DD'T and methoxychlor by bacteria. Appl Microbiol 26(1) 66-71

Johnston HW, Briggs GG, Alexander M (1972) Metabolism of 3-chlorobennoic acid by a pscudomonad. Soil Biol Biochem 4.187.190

Kamal Varsha S, Campbell-Wyndham R (1990) Anacrobic phototrophic metabolism of 3-chlorobenzoate by Rhodopseudomonas palustris WS17. Appl Environ Microbiol 56(12) 3871 . 3873

Keith L.H. Telliard WA (1979) Prionty pollutants Environ Su Technol 13(4):416.423

Kersten PJ, Dagley S, Whitiaker JW. Arciero D.M. I.apscomb JD (1982) 2-Pyrone-4,6-dicarboxylic acid, a calabolite of gallic acids in Pseudomonas species J Bactenol 152(3) 1154.1162

Kersten PJ, Chapman PJ, Dagley S (1985) Enzymalıc relcase of halogens or methanol from substituted protocatechuic acids I Bacteriol 162:693-697

Kilbane JJ, Chatterjec DK. Chakrabarty A.M (1983) Detoxification of 2,4,5-tnchlorophenoxyacetic acid from contaminated soil by Pseudomonas cepacia. Appl Finviron Microbiol 45·1697.1700

Kılpi S, Himberg K, Yrjala K, Backstrom V (1988) The degradation of biphenyl and chlorobiphenyls by mixed bactenal cultures. FEMS Microbiol Lett 53.19-26

Kumbara K. Hashımoto T, Iukuda M, Koana T. Takagı M. Oishı M, Yano K (1988) Isolation and characterisation of a mixed culture that degrades polychlorinated biphenyls. Agric Biol Chem 52(11):2885-2891

King GM (1988) Dehalogenation in manne sediments containing natural sources of halophenols Appl Environ Microbiol 54(12).3079.3085

Kirkpatrick D, Biggs SR. Conway B, Finn C.M, Hawkıns DR, Honda T, Ishida Mı, Powell GP (1981) Metabolism of N-(2,3-dichlorophenyl)-3,4,5,6-tetrachlorophthalamic acid (Techlofthalam) in paddy soil and nce. J Agnc Food Chem 29:1149-1153

Klages U. Lingens F (1979) Degradation of 4-chlorobenzoic acid by a Nocardia species. Fi:MS Microbiol Lell 6:201-203

Klages U, l.ıngens F (1980) Degradation of 4-chloroben/oic acid by a Pseudomonas sp. Z.bl Bakt Hyg. Abe OrigCl 1:215-223

Klages U, Markus A, Lingens F (1981) Degradation of 4-chlorophenylacetic acid by a Pseudomonas species. J Bacteriol 146:64.68

Klecka GM, Maier WJ (1985) Kinetics of microbial growth on pentachlorophenol. Appl Environ Microbiol 49(1):46-53

Knackmuss HI-J (1981) Degradation of halogenated and sulfonated hydrocarbons. In Leısınger T, Hutter R, Cook A.M. Nuesch J (eds) Microbial degradation of xenobiotics and recalcitrant compounds, Academic Press, London, Pp 189-212

Knackmuss H-J, Hellwig M (1978) Ciulisation and cooxidation of chlorinated phenols by Pseudomonas sp. B13 Arch Microbiol 117:1-7

Köcher H, Lingens F, Koch W (1976) Untersuchungen zum Abbau des Herbisıds Chlorphenpropmethyl im Boden und durch Mikroorganismen. Weed Res 16.93.100

Krueger James P, Butz Robert G, Atallah Yousef H, Cork Douglas J (1989) Isolation and identification of microorganisms for the degradation of Dicamba. J Agric Food Chem 37:534-538

Kuhm A, Schlömann M, Knackmuss H-J, Pieper D (1990) Punfication and characterisation of dichloromuconate cycloisomerase from Alcaligenes eutrophus JMP 134. Biochem J 266:877-883

Kuhn EP, Suflita JM (1989) Sequential reductıve dehalogenation of chloroanilines by microorganisms from a methanogenic aquifer. Environ Scı Technol 23:848-852

Kuwatsuka S, Igarashi M (1975) Degradation of PCP in soils II. The relauonship between the degradation of PCP and the properties of soils, and the identification of the degradation products of PCP. Soil Scı Plant Nutr 21(4):405-414

Latorre J, Reineke W, Knackmuss H-J (1984) Microbial metabolism of chloroanilines: enhanced evolution by natural genetic exchange. Arch Microbiol 140:159-164

Leisinger T, Brunner W (1986) Poorly degradable substances. In: Rehm H-J, Reed G (eds) Bıotechnology, vol 8, chapter 14, VCH Verlagsgesellschaft. Weinheim, pp 475-513 
Levine R, Chitwood DD (1985) Publıc health investigations of hazardous organic chemical waste disposal in the United States. Environ Health Perspect 62:415-422

Lingens F, Blecher R, Blecher H, Blobel F, Eberspächer J, Frohner C, Görisch H, Görisch H, Layh G (1985) Phenylobacterium immobile gen. nov., sp. nov., a Gram-negative bacterium that degrades the herbicide Chloridazon. Int J Sys Bacteriol 35(1):26-39

Liu D. Thomson K. Strachan WMJ (1981) Biodegradation of pentachlorophenol in a simulated aquatic environment. Bull Environm Contam Toxicol 26:85-90

L.u T, Chapman PJ (1984) Purification and properties of a plasmid-encoded 2,4-dichlorophenol hydroxylase I:EBS Iett 173:314-318

Loffler F, Muller R, L.ingens F (1991) A novel mechanism for an enzymatic dehalogenation reaction. Abstr Annu Mect VAAM March,18-21, 1991, Freiburg. FRG; published in: Bioforum 14(1/2):P164,p64

Loidl M, Hinteregger C, Ditıelmuller G, Ferschl A, Streıchsbier F (1990) Degradation of aniline and monochlorinated anılınes by soll-bom Pseudomonas acıdovorans strains. Arch Microbiol 155:56-61

Loos MA, Roberts R.N, Alexander M (1967a) Phenols as intermediates in the decomposition of phenoxyacetates by an Arthrobacter species. Can J Microbiol 13:679-690

Loos MA, Roberts R., Alexander M (1967b) Formation of 2,4-dichlorophenol and 2,4-dichloroanisole from 2,4-dichlorophenoxyacetate by Arthrobacter sp.. Can J Microbiol 13:691-699

Loos MA, Bollag J-M, Alexander M (1967c) Phenoxyacetate herbicide detoxification by bacterial enzymes. J Agnc Food Chem 15:858-860

l.udwig W, Eberspacher J, L.ıngens F, Stackebrandt E (1984) $16 \mathrm{~S}$ ribosomal RNA studies on the relationship of a Chlondazon-degrading Gram-negatıve eubacterium. System Appl Microbiol $5: 241-246$

Mackac K, Alexander M (1963) Metabolısm of phenoxyalkyl carboxylıc acids by a Flavobacterium species. J Bacienol 86:1231-1235

Magnus-Francis B (1990) Relatıve Icratogenicity of Nitrofen analogs in mice: Unchlorinated, monochlorinated, and dichlonnated-phenyl ethers. Teratology 41:443-451

Marks TS, Wait R, Smith ARW, Quirk AV (1984a) The origin of the oxygen incorporated during the dehalogenation/ hydroxylation of 4-chlorobenzoate by an Arthrobacter sp.. Biochem Biophys Res Commun 124(2):669-674

Marks TS, Smıth ARW, Quirk AV (1984b) Degradation of 4-chlorobenzoic acid by Arthrobacter sp. Appl Environ Microbiol 48:1020-1025

Markus A, Klages U, Krauss S, Lingens F (1984) Oxidation and dehalogenation of 4-chlorophenylacetate by a two-component enzyme system from Pseudomonas sp. strain CBS3. J Bacteriol 160:618-621

Meer JR van der, Neerven AR, Vries EJ, Vos WM, Zehnder AJB (1991) Cloning and characterisation of plasmid-encoded genes for the degradation of 1,2-dichloro-, 1,4-dichloro-, and 1,2,4trichlorobenzene of Pseudomonas sp. strain P51. J Bacteriol 173(1):6-15

Mikesell MD, Boyd SA (1986) Complete reductuve dechlorination and mineralisation of pentachlorophenol by anaerobic microorganisms. Appl Environ Microbiol 52:861-865

Mikescll MD, Boyd SA (1985) Reducuve Dechlorination of the pesticides 2,4-D, 2,4,5-T, and pentachlorophenol in anaerobic sludges. J Environ Qual 14(3):337-340

Mohn WW. Tiedje JM (1990) Strain DCB-1 conserves energy for growth from reductive dechlonnation coupled to formate oxidation. Arch Microbiol 153:267-271

Moon YH, Kuwatsuka S (1984) Properties and conditions of soils causing the dechlorination of the herbicıde benthiocarb (thiobencarb) in flooded soils. J Pest Sci 9:745-754

Morgan P. Watkınson RJ (1989) Microbiological methods for the cleanup of soil and ground water contaminated with halogenated organic compounds. FEMS Microbiol Rev 63:277-300

Morris CM, Barnsley EA (1982) The cometabolism of 1- and 2-chloronaphthalene by pseudomonads. Can J Microbiol 28(1):73-79

Mousa MA, Rogers JE (1990) Dechlorination of hexachlorobenzene in two freshwater pond sediments under methanogenic conditions. Abstr Ann Meet Amer Soc Microbiol Q-45:296

Müller R. Thiele Jürgen, Klages Uwe, Lingens Franz (1984) Incorporation of $\left({ }^{18} \mathrm{O}\right)$ Water into 4-hydroxybenzoic acid in the reaction of 4-chlorobenzoate dehalogenase from Pseudomonas spec. CBS 3. Biochem Biophys Res Commun 124(1):178-182

Murthy NBK, Kaufman DD, Fries GF (1979) - Degradation of pentachlorophenol (PCP) in aerobic and anaerobic soul. J Environ Sci Health 14(1):1-14

Neidleman SL, Geigert J (1987) Biological halogenation: roles in nature, potential in industry. Endeavour 11(1):5-15 
Neilson AH (1990) The biodegradation of halogenated organic compounds. J Appl Bactenol $69: 445 \cdot 470$

Neilson AH, Allard A.S, Hynnıng P.A, Remberger M (1988) Transformations of halogenated aromatic aldehydes by metabolically stable anacrobic ennchment cultures. Appl Environ Microbiol 54(9):2226.2236

Nesnow S, Argus M, Bergman H, Chu K, Inth C, Helmes T, McGaughy R, Ray V, Slaga TJ, Tennant R, Weisburger E (1986) Chemical carcinogens. A review and analysis of the literature of selected chemicals and the establishment of the Gene-Tox Carcinogen Data Base. Mutation Res 185:1-195

Ngai K-L, Schlomann M, Knackmuss H-J, Ornston L.N (1987) Dienclactone hydrolase from Pseudomonas sp. strain B13. J Bacteriol 169(2):699-703

Oltmanns RH, Rast HG, Reineke W (1988) Degradation of 1,4-dichlorobenzene by ennched and constructed bactena. Appl Microbiol Biotechnol 28.609.616

Oltmanns RH, Muller R, Oto MK, Lungens F (1989) Evidence for a new pathway in the bactenal degradation of 4-fluorobenzoate. Appl Environ Microbiol 55(10)·2499-2504

Omon T. Sugimura K. Ishigooka H, Minoda Y (1986) Purification and some properties of a 2-hydroxy-6-oxo-6-phenylhexa-2,4-dienoic acid hydrolyang enzyme from Psendomonas cruciviae S93 B1 involved in the degradation of biphenyl. Agnc Biol Chem 50(4):931-937

Ornston LN (1966) The conversion of catechol and protocatechuate to B-ketoadipate by Pseudomonas putida III. Enzymes of the catechol pathway J Biol Chem 241:3795-3799

Ornston L.Y. Stanicr RY (1966) The conversion of catechol and protocatechuate to B-ketoadipate by Pseudomonas putuda I. Biochemistry. J Biol Chem 241.3776.3786

Parsons JR, Ratsak C. Siekerman C (1990) Biodegradation of chlonnated dibenzofurans by an Alcaligenes strain. In: liutzanger O, Fiedler O (eds) Organohalogen compounds. Proc. Dioxun ' 90 EPRI Seminar, vol Vol 1, Fcoinforma Press, Bayreuth, PP 377-380

Pathak D. Ollis D (1990) Refined structure of dienelactone hydrolase at 1.8 A. J Mol Biol 214(2):497.425

Pathak D. Ngai K-L, Ollis D (1988) X-ray crystallographic structure of dienclactone hydrolase at 2.8 A. J Mol Biol 204:435-445

Peltigrew CA. Haigler BE. Spain JC (1991) Simultancous biodegradation of chlorobenzene and toluene by a Pseudomonas strain. Appl Environ Microbiol 57(1).157-162

Pieper DH, Reineke W, Engesser KII, Knackmuss H.J (1988) Metabolism of 2.4dichlorophenoxyacetıc acid, 4-chloro-2-methylphenoxyacelic acid and 2-methylphenoxyacetıc acid by Alcaligenes eutrophus JMP 134. Arch Microbiol 150:95-102

Pieper D (1986) Metabolismus von substutuierten Phenoxyacetaten. Phenolen und Benzosten durch Alcaligenes eutrophus JMP 134 und Derivate. PhD thesis Liniversity of Stultgan, FRG'202-203

Pignatello Joseph J, Martinson Michael M. Steicrt John J. Carlson Roben E, Crawford Ronald I. (1983) Biodegradation and photolysis of pentachlorophenol in artificial freshwater streams. Appl Environ Microbiol 46(5):1024-1031

Quensen (III) JF, Matsumura F (1983) Oxidative degradation of 2,3,7,8-tetrachlorodibenzo-p-dioxin by microorganisms. Environ Toxicol Chem 2.261-268

Quensen (III) JF. Tiedje JM. Boyd SA (1988) Reductive dechlonnation of polychlonnated biphenyls by anaerobic microorganisms from seduments. Science 242:752-754

Quensen (III) JF, Boyd SA, Tiedje JM (1990) Dechlonnation of four commercial polychlorinated biphenyl mixtures(Aroclors) by anaerobic microorganisms from sediments. Appl Environ Microbiol 56(8):2360-2369

Ramsay B, McCarthy J, Guerra-Santos L, Kappelı O, Fiechter A, Margaritis A (1988) Biosurfactant production and diauxic growth of Rhodococcus auranthiacus when using $n$-alkanes as the carbon source. Can J Microbiol 34.1209-1212

Rasul-Chaudry G, Chapalamadugu S (1991) Biodegradation of halogenated organic compounds. Microbiol Rev 55(1):59-79

Reber H, Helm V, Karanth NGK (1979) Comparative studies on the metabolism of aniline and chloroanilines by Pseudomonas multivorans strain An 1. Eur J Appl Microbiol 7:181-189

Reineke W (1986) Construction of bacterial strains with novel degradative capabiluties for chloroaromatucs. J Basic Microbiol 26(9):551-567

Reineke W, Knackmuss H-J (1978a) Chemical structure and biodegradability of halogenated compounds. Substituent effects on dehydrogenation of 3,5-cyclohexadiene-1,2-diol-1-carboxylic acid. Biochim Biophys Acta 542:424-429

Reineke W, Knackmuss H-J (1978b) Chemical structure and biodegradability of halogenated aromatic compounds. Sustituent effects on 1,2-dioxygenation of benzoic acids. Biochim Biophys Acta 542:412-423 
Reineke W, Knackmuss H-J (1984) Microbial metabolism of haloaromatics: Isolation and properties of a chlorobenzene- degrading bacterium. Appl Environ Microbiol 47:395-402

Reineke W. Knackmuss H-J (1988) Microbial degradation of haloaromatics. Ann Rev Microbiol 42:263-287

Renganathan V (1989) Possible involvment of toluene 2,3-dioxygenase in defluorination of 3-fluoro-substituted benzenes by toluene-degrading Pseudomonas sp. strain T-12. Appl Environ Microbiol 55(2):330-334

Renner G, Nguyen Phuc-Trung (1984) Mechanısms of the reductive denitration of pentachlorontrobenzene $(\mathrm{PCNB})$ and the reductuve dechlonnation of hexachlorobenzene(HCB). Xenobiotica 14(9):705-710

Ribbons DW, Cass AEG, Rossiter JT, Taylor SJC, Woodland MP (1987) Biotransformations of fluoroaromatic compounds. J Fluorine Chem 37:299-326

Rippen G, Frank R (1986) Estimation of hexachlorobenzene pathways from the technosphere into the environment. In: Morris CR, Cabral JRP (eds) Hexachlorobenzene: Proceedings of an intemational symposıum, Oxford University Press, Oxford, pp 45-52

Rippen G, Klopffer W, Frische R, Gunther K (1984) The environmental model segment approach for estumatung potentıal environmental concentrations. Ecotoxicol Environ Safety 8:363-377

Rochkınd-Dubınsky ML, Sayler GS, Blackburn JW (1986) Microbial decomposition of chlorinated aromatic compounds, vol Microbiology senes, chapter 18, Marcel Dekker Inc, New York and Basel

Rot B, Nitz S, Kone F (1979) Microbial decomposition of sodium pentachlorophenolate. J Agric Food Chem 27:306-310

Rubio MA, Engesser K-H, Knackmuss H-J (1986a) Microbial metabolism of chlorosalycylates: accelerated evolution by natural genetic exchange. Arch Microbiol 145:116-122

Rubıo MA, Engesser K-H, Knackmuss H-J (1986b) Microbial metabolism of chlorosalicylates: effect of prolonged subcultuvation on constructed strains. Arch Microbiol 145:123-125

Ruısinger S, Klages U, Lingens F (1976) Abbau der 4-Chlorbenzoesäure durch eine ArthrobacterSpecies. Arch Microbiol 110:253-256

Ryan J, Gasiewicz TA, Brown( jr.) JF (1990) Human body burden of polychlorinated dibenzofurans associated with toxicity based on the Yusho and Yucheng incidents. Fundamental Appl Toxicol $15: 722-731$

Saber DL, Crawford RL (1985) Isolation and characterisation of Flavobacterium strains that degrade pentachlorophenol. Appl Environ Microbiol 50:1512-1518

Sabljic A (1989) Quantıtatıve modelıng of soil sorption for xenobiotic chemicals. Environ Health Perspect 83:179-190

Safe SH (1984) Microbıal degradation of organic compounds. In: Gibson DT (ed), vol 13 Microbial degradauon of polychlonnated biphenyls, Marcel Dekker, Inc, New York pp 361-369

Safe S (1990) Polychlonnated biphenyls (PCBs), dibenzo-p-dioxins(PCDDs), dibenzofurans(PCDFs), and related compounds: environmental and mechanistic considerations which support the development of toxic equivalency factors (TEFs). Crit Rev Toxicol 21(1):51-88

Sato K. Tanaka H (1987) Degradation and metabolism of a fungicide, 2,4,5,6-tetrachlororsophthalonitnle (TPN) in soil. B1ol Feril Soils 3:205-209

Sauber K, Fróhner C, Rosenberg G, Eberspächer J, Lingens F (1977) Purification and properties of a Pyrazon dioxygenase from Pyrazon-degrading bacteria. Eur J Biochem 74:89-97

Savard P. Peloquin L. Sylvestre M (1986) Cloning of Pseudomonas sp. strain CBS3 genes specifying dehalogenation of 4-chlorobenzoate. J Bacteriol 168(1):81-85

Schacht S, Engesser K-H, Dom E, Knackmuss H-J (1991) Biodegradation of 4-halosubstituted benzoates via meta-cleavage pathway: Characterisation of unproductive metabolism by Pseudomonas putida mt-2 (Subrnitted for publication to Arch. Microbiol)

Schenk T, Müller R, Mörsberger F, Otto MK, Lingens F (1989) Enzymatic Dehalogenation of pentachlorophenol by extracts from Arthrobacter sp. strain ATCC 33790. J Bacteriol 171(10):5487.5491

Schenk T, Müller R, Lingens F (1990) Mechanism of enzymatic dehalogenation of pentachlorophenol by Arthrobacter sp. strain ATCC 33790. J Bacteriol 172(12):7272-7274

Schennen U, Braun K, Knackmuss H-J (1985) Anaerobic degradation of 2-fluorobenzoate by benzoate-degrading, denitrifying bacteria. J Bacteriol 161(1):321-325

Schlömann M, Schmidt E, Knackmuss H-J (1990a) Different types of dienelactone hydrolase in 4-fluorobenzoate-utilising bacteria. J Bacteriol 172(9):5112-5118

Schlömann M, Fischer P, Schmidt E, Knackmuss H-J (1990b) Enzymatic formation, stability, and spontaneous reactions of 4-fluoromuconolactone, a metabolite of the bacterial degradation of 4-fluorobenzoate. J Bacteriol 172(9):5119-5129 
Schmidt E, Knackmuss H-J (1980) Chemical structure and biodegradability of halogenated aromatic compounds Conversion of chlorinated muconic acids into maleoylacetic acid. Biochem J 192:339-347

Schmidt E. Remberg G, Knackmuss H-J (1980) Chemical structure and biodegradability of halogenated aromatic compounds Halogenated muconic acids as intermediates. Biochem J 192:331-337

Schmitt S, Muller R, Wegst W, l.ıngens F (1984) Chlondazon-catechol dioxygenases, a distınct group of meta-cleaving en rymes Hoppe-Seyler's Z Physiol Chem 365:143.150

Schraa G, Boone ML, Jetten MSM, Neerven AR, Colberg PJ, Zehnder AJB (1986) Degradation of 1,4-dichlorobenzene by Alcaligenes sp. strain A175. Appl Environ Microbiol 52(6):1374-1381

Schreiber A, Hellwig M, Dorn F, Reineke W, Knackmuss H-J (1980) Critical reactions in fluorobenzoic acid degradation by Pseudomonas sp. B13. Appl Environ Microbiol 39:58-67

Schukat B, Janke D, Krebs D, Fntsche W (1983) Cornetabolic degradation of 2- and 3-chloroaniline because of glucose melabolism by Rhodococcus sp. An 117. Curr Micrubiol 981.86

Shalubhaı K, Sahasrabudhe SR, Vora KA. Modı VV (1983) Degradauon of chlonnated denvatives of phenoxyacelic acid and benzolc acid by Aspergillus niger. FE.MS Microbiol Lell 18 279.282

Sharak-Genthner BR, Allen-Price II W, Pnichard PH (1989a) Characterisation of anacrobic dechlorinating consortia derived from aquatic sediments Appl inviron Microbiol 55(6): $1472-1476$

Sharak-Genthner BR, Allen-Price II W, Pritchard PII (1989h) Anacrobic degradation of chloroaromatic compounds in aquatic sediments under a variety of ennchment conditions Appl Environ Microbiol 55(6) 1466-1471

Shelton DR. Tiedje JM (1984) Isolation and partial characterisation of bacteria in an anacrobic consortium that muneralises 3-chlorobenzoic acid Appl Environ Microbiol 48(4) 840)-848

Shians MP. Sayler GS (1982) Biotransformation of PCB by natural assemblages of freshuater microorganisms. linviron Sci Technol 16.367-369

Shields MS, Hooper SW. Sayler GS (1985) Plasmid-mediated mincralisation of 4-chlorohiphenyi J Bactenol 163(3) 882.889

Shimao M, Omishı S, Mizumon S. Kato N, Sakazawa C (1989) Degradauon of 4-chlorobenzoate by facultatuvely alkalophilic Arthrobacter sp. strain SB8. Appl Environ Microbiol 55(2):478.482

Siuda JF, DeBemardis JF (1973) Vaturally occuning halogenated compounds. LJuydia 36:107-143

Skaare JU, Polder A (1990) Polychlonnated biphenyls and organochlonne pesticides in milk of Norwegian women during lactation Arch Environ Contam Toxicol 19 640-645

Spain JC, Nishino SF (1987) Degradation of 1,4-dichlorobenzene by a Pseudomonas sp Appl Environ Microbiol 53(5):1010.1019

Span JC, Gibson DT (1988) Oxidation of substututed phenols by Pseudomonas putida F1 and Pseudomonas sp strain JS6 Appl Environ Microbiol 54: 1399-11404

Spert GT, Harvey J (1988) Microbial adaptation to bromobeniene in a chemostat Curr Microbiol 17:99-103

Springer W, Rast HG (1988) Biologischer Abbau mehrfach halogeniener mono- und polyayklischer Aromaten gwf Wasser/Abwasser 129 (1) 70-75

Steiert JG. Pignatello JJ, Crawford RL (1987) Degradation of chlonnated phenols by a pentachlorophenol-degrading bactenum. Appl Environ Microbiol 53:907-910

Stepp TD, Camper ND, Paynter MJB (1985) Anacrubic microbial degradation of selected 3,4-dihalogenated aromatic compounds. Pest Biochem Physiol 23.256-260

Strubel V. Engesser KH, Fischer p. Knackmuss H.J (1991) 3-(2-Hydroxyphenyl) catechol as substrate for proximal meta nng cleavage in dibenzofuran degradation by Brevibacterium sp strain DPO 1361. J Bactenol 173(6): 1932-1937

Struijs J. Rogers JE (1989) Reductive dehalogenation of dichloroanılınes by anaerobic microorganisms in fresh and dichlorophenol-acclimated pond sediment. Appl Environ Microbiol $55(10): 2527.2531$

Suflita JM, Horowitz A. Shelton DR. Tiedje JM (1982) Dehalogenation: a novel pathway for the anaerobic biodegradation of haloaromatic compounds. Science 218:1115-1117

Suflita JM. Stovt J, Tiedje JM (1984) Dechlorination of (2,4,5-trichlorophenoxy)acetic acid by anaerobic microorganisms. J Agric Food Chem 32:218

Surovtseva EG, Volnova AI, Shatskaya TYa (1980) Degradation of monochlorosubstututed anilines by Alcaligenes faecalis. Mikrobıologiya 49:351-354

Surovtseva EG, Ivoilov VS, Karasevich YuN (1986) Metabolism of chlonnated anilınes by Pseudomonas diminuta. Mikrobiologiya 55:591-595

Suzuki T (1977) Metabolism of pentachlorophenol by a soll microbe. J Environ Sci Health 12:113-127 
Sylvestre M, Mallhot K, Ahmad D, Masse R (1989) Isolation and preliminary characterisation of a 2-chlorobenzoate degrading Pseudomonas. Can J Microbıol 35:439-443

Siew ryk U. Szewzyk R, Schink B (1985) Methanogenic degradation of hydroquinone and catechol via reductıve dehydroxylation to phenol. FEMS Microbiol Ecol 31:79-87

Taylor BF, Ileam WI. Pincus S (1979) Metabolısm of monofluoro- and monochlorobenzoates by a denitnfying bacterium. Arch Microbiol 122:301-306

Thicle J, Muller R, l.ıngens F (1987) Intial characterisation of 4-chlorobenzoate dehalogenase from Pseudomonas sp. CBS3 IFI:MS Microbiol lett 41:115-119

Thiele J. Muller R, lingens F: (1988) Enzymatic dehalogenation of 4-chlorobenzoate by 4-chlorobenzoate dehalogenase from Pseudomonas sp. CBS3 in organic solvents. Appl Microbiol Biotechnol 27.577-580

Tibbles PE:, Muller R, l.ıngens F (1989a) Microbial metabolism of quinoline and related compounds 1II. Degradation of 3-chloroquinoline-8-carboxylic acid by Pseudomonas spec. EK III. Biol Chem Hoppe-Seyler 3701191.1196

Tibbles Pl:, Muller R, I.ıngens I: (1989b) Degradation of 5-chloro-2-hydroxynicotinic acid by Mycobactenum ip BA. Biol Chem Hoppe-Seyler 370:601-606

Tiedje JM. Alexander M (1969) Enzymatic cleavage of the ether bond of 2.4.dichlorophenoxyacetate. J Agnc Food Chem 17:1080-1084

Ticdje JM, Duxburry JM, Alexander M. Dawson JE (1969) 2,4-D metabolism: Pathway of degradation of chlorocatechols by Arthrobacter sp. J Agric Food Chem 17:1021-1026

Tittmann $\mathrm{C}$, Wegst W, Blecher R, l.ıngens F (1980) Abbau von trans-Zimtsaiure durch Chloridazonabbauende Bakterien /hl Bakt Hyg I Abt Orig Cl:124-132

Tsuchiya Tushic, Yamaha Tsutomu (1984) Reductive dechlonnation of 1,2,4-trichlorobenzene by Staphylococcus epidermidis isolated from intestunal contents of rats. Agric Biol Chem $48(6) 1545 \cdot 1550$

Tweel WJJ van den, Burg N, Kok JB, de Bont JAM (1986) Bioformation of 4-hydroxybenzoate from 4.chloroben/sate by Alcaligenes denutrificans NTB-1. Appl Microbiol Biotechnol 25:289-294

Tweel WJJ van den. Kok JB, de Bont JAM (1987) Reductive dechlorination of 2,4-dichloroben/oate to 4-chloroben/oate and hydrolytic dehalogenation of 4-chloro-, 4-bromo-, and 4-1odoben/oatc by Alcaligenes denurificans NTB-1. Appl Environ Microbiol 53(4):810-815

Valo R, Salkınoja-Salonen M (1986) Bioreclamation of chlorophenol-contaminated soil by composting Appl Microbiol Biotechnol 25:68-75

Vandenbergh PA. Olsen RH. Colaruotolo JF (1981) Isolation and genetic characterisation of baciena that degrade chloroaromatic compounds. Appl Environ Microbiol 42(4):737-739

Vincy I, Bewley RJF (1990) Prelıminary studies on the development of a microbiological treatment for polychlorinated hiphenyls. Arch Environ Contam Toxicol 19:789-796

Vora KA, Singh C, Modı VV (1988) Degradation of 2-fluorobenzoate by a pseudomonad. Curr Microbiol 17:249.254

Wannstedt C. Rotella D, Siuda JF (1990) Chlonoperoxidase mediated halogenation of phenols. Bull Environ Contam Toxicol 44 282-287

Watanabe I (1973) Isolation of pentachlorophenol decomposing bacteria from soil. Soil Sci Plant Nutr 19:109-116

Wedemeyer G (1967) Dechlorination of 1,1,1-trichloro-2,2-bis(p-chlorophenyl)ethane by Aerobacter aerogenes. Appl Microbiol 15:569-574

Whitlock JP (1990) Genetic and molecular aspects of 2,3,7,8-tetrachlorodibenzo- $\rho$-dioxin action. Ann Rev Pharmacol Toxicol 30 251-277

Wittich R-M, Sander P. Fortnagel P (1989) Aerobic degradation of 1,2,4-trichlorobenzene (1,2,4TCB) and 1,2,4,5-tetra-chlorobenzene $(1,2,4,5-\mathrm{TeCB})$ by pure cultures of soil bacteria (Abstr. Annu. Mect Germ Soc. Microbiol., P243). forum mikrobiologie(1-2):100

Wittıch R-M. Schmıdt S, Fortnagel P (1990) Bacterial degradation of 3- and 4-carboxybiphenyl ether by Pseudomonas sp. NSS2 FEMS Microbiol Lett 67,157-160

Xun L. Orser CS (1991) Biodegradation of triiodophenol by cell-free extracts of a pentachlorophenol-degrading Flavobacterium sp.. Biochem Biophys Res Cormmun 174(1):43-48

Yamada T, Suzuki T (1983) Occurence of reductive dechlorination products in the paddy field soil treated with CNP (Chlomitrofen). J Pest Sci 8(4):437-443

Yeh W.K. Shih C. Omston L.N (1982) Overlapping evolutionary affinities revealed by comparison of amino acid compositions. Proc Natl Acad Sci USA 79:3794-3797

7aitsev GM, Karascvich YuN (1985) Preparatory metabolism of 4-chlorobenzoic and 2,4dichlorobenzolc acids in Corynebaclerium sepedonicum. Mikrobiologiya 54(3):356-359

7cyer J. Wasserfallen A. Timmis KN (1985) Microbial mineralisation of ring-substituted anilines through an ortho-cleavage pathway. Appl Environ Microbiol 50(2):447-453 
Zhang X, Wiegel J (1990) Sequential anaerobic degradation of 2,4-dichlorophenol in freshwater sedıments. Appl Environ Microbiol 56(4):1119-1127 